\title{
Achieving the best method to classify Eosinophilic Chronic Rhinosinusitis: a systematic review*
}

\author{
Mariana Dalbo Contrera Toro', Marcelo Augusto Antonio', Mariah Guieiro \\ Alves dos Reis', Maíra Seabra de Assumpção², Eulalia Sakano
}

' Department of Ophthalmology and Otorhinolaryngology, University of Campinas (Unicamp), Faculty of Medical Sciences, Campinas, São Paulo, Brazil

2 Pulmonary physiology lab, Pediatrics Investigation Center, Department of Pediatrics, Faculty of Medical Sciences, State University Accepted: February 15,2021 of Campinas, Campinas, São Paulo, Brazil

\begin{abstract}
Background: Chronic Rhinosinusitis is currently classified into eosinophilic and non-eosinophilic, according to the histologic quantification of the number of eosinophils in nasal mucosa biopsy. There is a lack of unanimous histopathologic criteria and methodology for this classification and no consensus regarding a cut-off point for Eosinophils per High power field.
\end{abstract}

Methodology: A systematic electronic search was performed on BVS, PUBMED, PUBMED PMC, SCOPUS, WEB OF SCIENCE, EMBASE, COCHRANE and PROQUEST databases looking for studies that reported a cut point for classification of Eosinophilic Chronic Rhinosinusitis (eCRS), and data concerning methodology of classification was extracted.

Results: We identified 142 studies that reported 29 different cut-off values for classification of eCRS, and different methods of histologic analysis. Out of these studies 13 reported their own methodology to establish the cut-off point, and used different reference standards as polyp recurrence, asthma and allergy, immunocytochemistry, quality of life index, standard deviation of the control population and cluster analysis.

Conclusions: Further studies are needed to determine a precise cut-off point, especially international multicentered cluster analysis. Moreover, methodologic standardization of biopsy and analysis is needed to certify comparable results. Multiple biopsy sites, densest cellular infiltration area examination and oral steroids restriction at least four weeks before sampling are advisable

Key words: sinusitis, nasal polyps, eosinophils, cell count

\section{Introduction}

Chronic rhinosinusitis (CRS) is the inflammation of nasal and sinus mucosa ${ }^{(1)}$. Nowadays, most otorhinolaryngologists acknowledge the classification of CRS in different phenotypes. These phenotypes lack detailed comprehension of the underlying immunologic and inflammatory mechanisms of CRS. This heterogeneity supports the concept that CRS consists of multiple biological subtypes, or endotypes, which are defined by different pathophysiologic systems that might be recognized by distinct biomarkers ${ }^{(2)}$. The inflammatory patterns of nasal polyps are generally defined to be Type 2 inflammation and Non-Type 2 according to the predominant inflammatory cell type (eosinophils or neutrophils), and mediator or cytokine expression (3). Endotypes of CRS can be classified according to specific immune inflammatory and remodeling profiles, circulating biomarkers, responsive to treatment (effect of immunobiological drugs, resistance to antibiotics and corticosteroids), and aspirin sensitivity ${ }^{(2)}$.

Facing so many possibilities, the EPOS2020 steering group has chosen to look at CRS in terms of primary and secondary and to divide each into localized and diffuse diseases based on anatomic distribution. In primary CRS, the disease is classified according to endotype dominance, either of type 2 or non-type 2. For diffuse CRS, the clinical phenotypes are predominantly eosinophilic chronic rhinosinusitis (eCRS) and non-eosinophilic Chronic Rhinosinusitis (non-eCRS), determined by the histologic quantification of the number of eosinophils, agreed to be $\geq 10$ eosinophils/high power field (eos/HPF) as per the EPOS panel ${ }^{(1)}$. 
Although a meta-analysis stated that a $>55$ eos/HPF cut-off point value is useful in predicting the likelihood of recurrence (4), the cut-off value to the histologic eCRS classification itself is far from a consensus. The literature has paid increasing attention to the differentiation between eCRS and non-eCRS, but there is a lack of unanimous histopathologic criteria for it, given its controversial nature ${ }^{(4)}$. Some studies defined tissue eosinophilia based on eosinophil count per HPF (400x), while others were based on the proportion of the eosinophil cell count as a percentage of the total inflammatory cell count in the sample. Although some researchers suggested absolute numbers/HPF like 5, 8, $10,70100,120,350$ as appropriate cutoffs, others considered eosinophil percentage ranges like $5,10,11,20$ or as high as $50 \%$ count as relevant cutoff values of eCRS ${ }^{(5)}$. Conflicting with the European Rhinologic Society, which suggests a cut-off value of 10 eos/HPF, the Japanese JESREC study established a 70 eos/HPF limit in classifying eCRS $(1,6)$.

There is an urgent need to unify methodologies and to specify clear and practical values for histopathologic eCRS, in order to expand studies comparison and to tailor personal treatment to different populations around the globe. This study aims to identify the different histological methodologies used to classify eCRS in the literature, and subsequently verify the cut-off points of the eosinophil counting used in this classification.

\section{Materials and methods}

Data sources and search strategy

A systematic electronic search was performed on BVS, PUBMED, PUBMED PMC, SCOPUS, WEB OF SCIENCE, EMBASE, COCHRANE and PROQUEST databases until January 20th, 2020. The Medical Subject Headings (MeSH) descriptors used in the preliminary search strategy were "sinusitis", "nasal polyps", "eosinophils" and "cell count".

However, in order not to miss important articles, we had to exclude the descriptor "cell count". A search strategy was designed for each database (Appendix 1) to identify all studies on eCRS with nasal polyps. Duplicities were excluded using Endnote ${ }^{\oplus}$ and manually.

A systematic review was performed to identify studies that reported the methodology used for eosinophilic histologic classification of CRS patients. This review was done in accordance with the items described in the Preferred Reporting Items for Systematic Reviews and Meta-Analyses (PRISMA) ${ }^{(7)}$.

\section{Study selection}

The studies were reviewed by two independent authors (MDCT and MAA) and selected according to the eligibility criteria. Titles and abstracts were screened using the Rayyan app for systematic reviews ${ }^{\left({ }^{(8)}\right.}$. Conflicts between authors were solved by a third author (ES). In a second phase full texts of the selected abstracts were then analyzed and included if meeting the selection crite- ria. Lastly, missing studies were searched manually after being identified in the bibliography of included studies.

\section{Eligibility criteria}

The studies selected had patients classified with CRS according to the EPOS ${ }^{(1,9)}$, and biopsy for histologic eosinophil count evaluation. Articles were included when they presented a clear methodology regarding the classification of eosinophilia by showing a cutoff value, even when classifying it in eosinophilia groups or in clusters. The following study designs were considered: case-control, cross-sectional, experimental and cohort. Studies published after the year of 2000 in English, Spanish, French and Portuguese were included.

Case reports, case series, reviews, guidelines, letters, congress abstracts, and editorials were excluded along with animal studies. When other parameters different from histopathologic biopsies analysis, since immunohistochemistry or exclusive clinical classification were used to classify eCRS, papers also were excluded, as well as studies that conducted a subjective histopathologic analysis, with no clear criteria for classifying eosinophilic tissues.

The outcome of interest in our first analysis was the method used to histologically classify eCRS, so all studies that specified a cut off point for eosinophil counting were included. In our secondary examination to verify the best cut-off point for histological evaluation we searched within the bibliography of the studies included and selected only the articles that demonstrated an original threshold of eosinophil count.

\section{Data extraction}

An Excel standardized data-sheet was used to extract relevant data from the selected articles, such as first author name, year of publication, study methodology, population, site of biopsy sampling, the classification of eCRS (clinic score and histologic), the cut-off value for eCRS, treatment when biopsy was performed, cited literature to justify the classification used, and method of eosinophil count (number of examiners, if examiners were blinded, number of HPF counted, and how the HPF were selected). After this initial selection we analyzed the articles that were cited by the authors as references to define the cut-off value, along with those that established an original research to prove an optimal cut-off point, and each of the mentioned articles were examined individually. Data from those studies were extracted using the following topics: First author name, year of publication, nationality of the study, population, study design, cut off value for eCRS, the reason used to justify the cut-off point, and the method for identification of a specific threshold.

Descriptive data were presented in percentages and proportions. Characteristics of the studies and details of the information were summarized in tables. Graphical data were displayed in figures. 


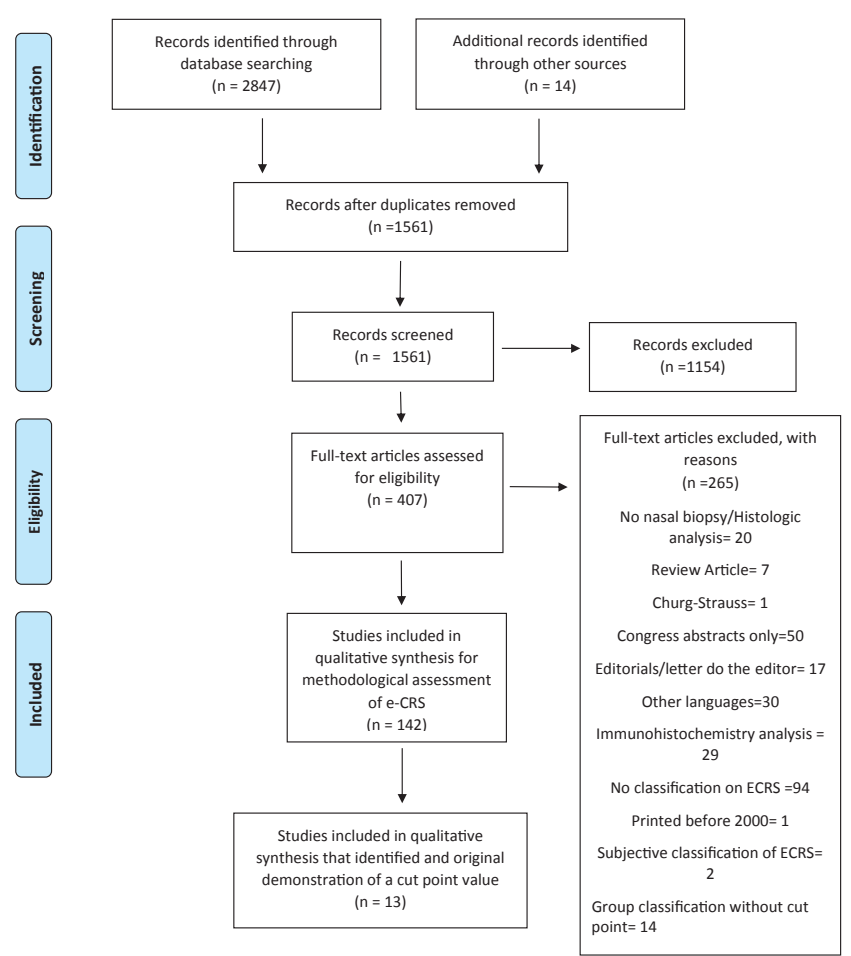

Figure 1. Study selection process based on PRISMA flowchart.

Assessment of methodological quality for included studies Articles that demonstrated their own methodology for assessing the classification of eosinophilia, were then analyzed separately using the Quality Assessment Tool for Observational and Crosssectional Cohorts developed by the National Heart, Lung, and Blood Institute (NHLBI), with 14 different criteria ${ }^{(10)}$. The articles were the classified by a Score previously published in the literature ${ }^{(11)}$. Because questions concerning exposure and outcome quality of the studies did not necessarily reflect on the eCRS cut-off point, and cross-sectional designs don't allow measure of time between exposure and outcome, questions 6-10 were answered and "not applicable". Every answer "Yes" to the criteria scored 1 point (0-9). A score higher than 7: "good", 4 a 7: "fair" and <4: "poor".

\section{Results}

\section{Study selection}

The search strategy yielded 2847 studies in total. Additionally, 14 studies were manually included after being identified via other sources. Checking for duplicates decreased the number to 1561. All titles and abstracts were then screened, resulting in 407 studies for assessment. Regarding the two objectives of this study, up to this stage the same criteria were used, and after checking eligibility by reading full texts, 142 studies were included, out of which 4 studies consisted of cluster analysis studies. Those articles were used to analyze the different histological methodologies used to classify eCRS.

Of these 142 studies, 13 were selected after meticulous analysis of the cited literature to justify the cutoff value for counting eosinophils in all articles, as well as the selection of articles that offered an original method for choosing the cutoff value. Those articles were used to verify the optimal cut points of eosinophils counts used to classify eCRS. Figure 1 shows a PRISMA based flowchart of the study selection.

\section{Histological methodologies used to classify eCRS}

Summarized information on the 142 studies selected to review methodologic histologic classification of eCRS are shown in Appendix 2.

\section{Population}

In addition to subjects with Chronic rhinosinusitis with nasal polyps (CRSwNP), some studies also verified Chronic rhinosinusitis without nasal polyps (CRSsNP) participants, controls. There were 88 studies from Asia, 23 from Europe, 20 from America, 7 from Oceania and 4 collaborations between Eastern and Western countries. China contributed with 32 studies, Japan with 31, the USA with 19, and South Korea with 18 studies.

\section{Biopsy site}

A great variety of biopsy sites were reported for CRS participants. One hundred studies reported nasal polyps' biopsy and nine of them specified the exact location (apex or middle meatus). There are 30 mentions on biopsies of ethmoids, 4 on uncinate process, and 3 on maxillary sinuses. Inferior turbinate and osteomeatal complex tissue were mentioned by one author. Also, 18 studies did not report a location, and 8 studies reported it nonspecifically as "sinus" or "nasal mucosa".

\section{Treatment at time of biopsy}

Many treatments were described before the nasal biopsy, the majority restricting one or more medications. In total, 36 studies did not mention any drugs used at time of biopsy, seven studies reported use of antibiotics, systemic and topic steroids, antihistamines and immunosuppressant drugs instead of restriction. Five studies had patients both on restriction of a drug category and prescription of other drugs category.

Systemic steroids were the most restricted drug, Figure 2 shows the different times of restriction for systemic and nasal topic steroids in studies that informed this category of drug restriction. Twenty-nine studies restricted antibiotics for 4 weeks prior to biopsy. Antileukotrienes were restricted in 13 studies, antihistamines in 12 and immunomodulators in general, in 17. The use of anti-inflammatory drugs, decongestants, immunotherapy, non-steroidal and anti-lgE drugs were cited as restricted, but less frequently.

\section{Method of eosinophil counting}

The number of pathologists or researchers that independently 

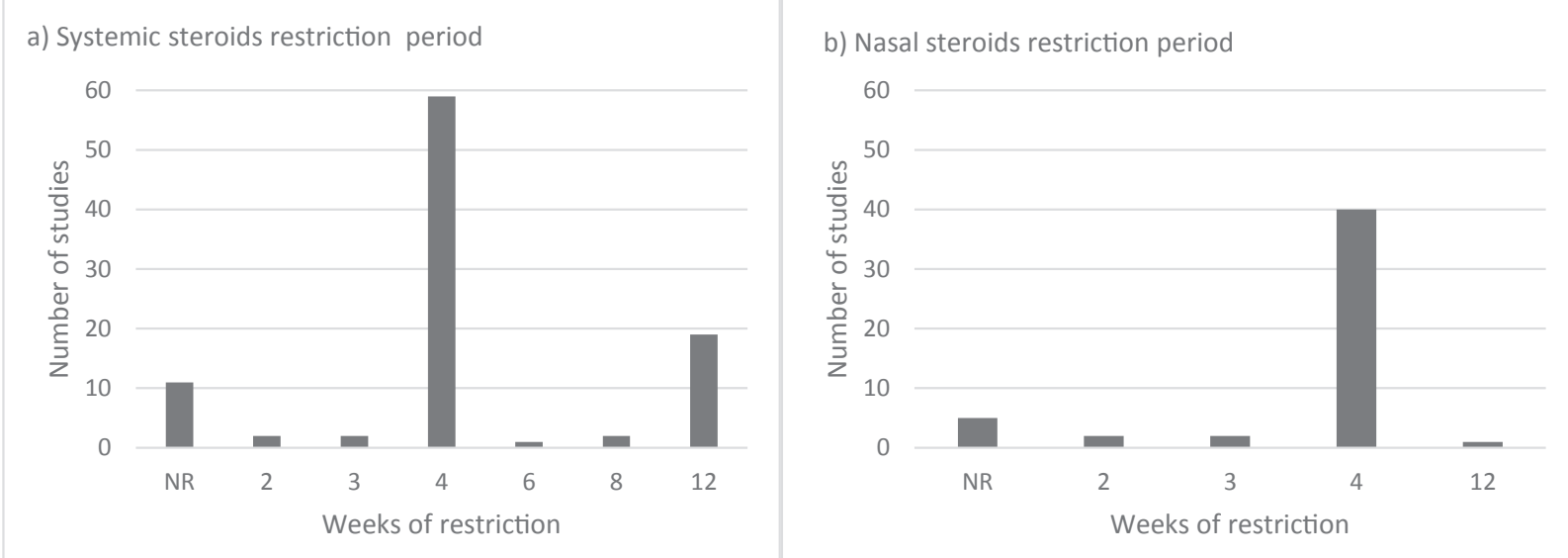

Figure 2. Time of systemic steroids restriction ( $a$ ) and Nasal steroids restriction (b) before biopsy.

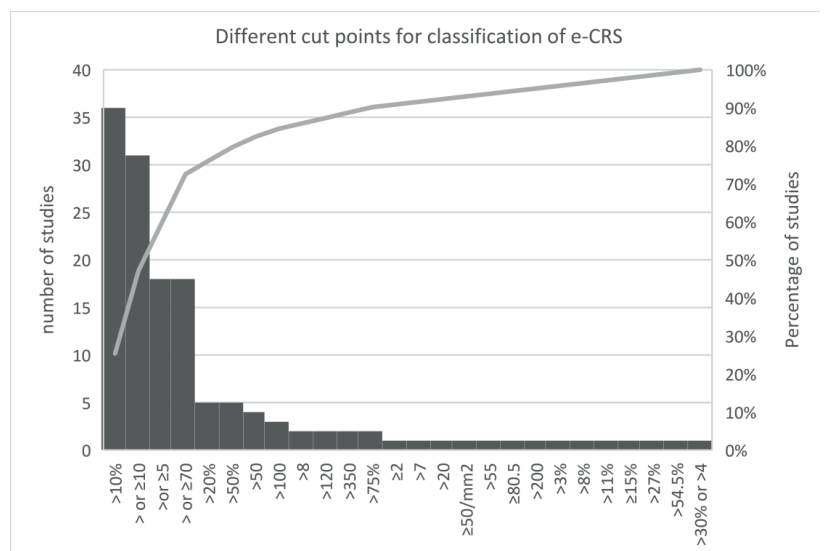

Figure 3. Different cut points of eosinophils both in absolute and relative percentage for classification of ECRS.

counted the eosinophils were not reported in 76 studies (53.5\%). Forty studies reported two independent examiners, 20 had a sole pathologist, and six articles reported 3 examiners. Forty-nine studies (34.5\%) reported the pathologists' blindness to the patient's clinical data.

Almost half of the studies (42.3\%) did not report the number of High-Power Fields (HPF X 400) used to count eosinophils and 25 (17.6\%) considered 10 HPF. The HPF selection was random in $20.4 \%$ of cases, and the densest area of cellular infiltration was chosen in $58.5 \%$ of the studies.

Eighty-four studies (59.2\%) used the absolute average of eosinophils/HPF to determine the cut-off value of eCRS, while 51 (35.9\%) used a percentage of eosinophils/ number of inflammatory cells for the classification. Four experiments used both the absolute and the percentile count. One author counted the number of eosinophils $/ \mathrm{mm}^{2}$, one used the ratio of eosinophils/ inflammatory cells associated with a thickened basal membrane, and one classified as eCRS when two or more HPF met the cutoff value.

\section{Classification of CRS}

Most studies (88\%) used histologic eosinophil counting alone to classify CRS as eosinophilic or non-eosinophilic. Two of these classified as eCRS whenever the percentage of double-folded eosinophils exceeded twice the standard deviation (SD) of the mean of controls. Twelve studies (8.5\%) combined the JESREC criteria associated with the histologic eosinophil count. Two classified as eosinophilic the combination of the histologic eosinophil count with the evidence of nasal polyps and allergic mucin.

There were 29 different cut-off values for the reported eCRS, 17 being absolute counts, 11 percentages of eosinophils/inflammatory cells, and one study reporting an absolute number of $\mathrm{eos} / \mathrm{mm}^{2}$. We decided to merge cut-off point values that only differentiate using the $\geq \operatorname{symbol}(>5 / \geq 5 ;>10 / \geq 10 ;>70 / \geq 70)$. The most frequent cut-off value was $>10 \%$, mostly representing Chinese studies, followed by the absolute count of $>$ or $\geq 10$, and $>$ or $\geq 70$, mostly representing Japanese studies (Figure 3).

Only 4 cluster analysis studies were included. Nakayama et al. ${ }^{(12)}$ conducted a retrospective study in Japan with 435 patients presenting CRS. Five factors within 16 variables were chosen to perform cluster analysis: symptom score, perennial allergy, disease severity (CT polyp score), asthma and eosinophil count. The patients were divided into 4 clusters and eosinophil count $\geq 80.5$ was the optimal cut-off point value.

Lou et al. ${ }^{(3)}$ included only CRSWNP patients. Five clusters were created: Cluster 1: Plasma-cells dominant phenotype; Cluster 2: Lymphocyte dominant phenotype; Cluster 3: Mixed inflammatory phenotype (Mean eos\% 40.55); Cluster 4: Neutrophil-dominant phenotype; Cluster 5: Eosinophil-dominant phenotype (Mean eos\% 79.28). The cut-off value for eCRS and Cluster 5 was $54.5 \%$, and this cluster had the highest recurrence rate (98.5\%). Liao et al. ${ }^{(13)}$ enrolled 246 CRS patients. The eCRS was used as classfication when polyp or ethmoid samples had more 
Table 1. Cut point for e-CRS classification: summary of findings of studies presenting its own methodology to establish a cut-off value.

\begin{tabular}{|c|c|c|c|c|c|c|}
\hline Author & $\begin{array}{l}\text { Nation- } \\
\text { ality }\end{array}$ & Population & Study Design & Cut-off Value & $\begin{array}{l}\text { Reason of } \\
\text { Cut-off }\end{array}$ & Method for the Cut-off establishment \\
\hline $\begin{array}{l}\text { Cao } \\
2009^{(14)}\end{array}$ & China & $\begin{array}{l}50 \text { Controls } \\
94 \text { CRSsNP } \\
151 \text { CRSwNP } \\
\text { (70 e-CRS and } \\
81 \text { non-eCRS) }\end{array}$ & $\begin{array}{l}\text { Prospective, Ob- } \\
\text { servational, Cross- } \\
\text { sectional study }\end{array}$ & $\begin{array}{l}>10 \% \text { of the } \\
\text { inflammatory } \\
\text { cells }\end{array}$ & $\begin{array}{l}\text { Twice the } \\
\text { SD of the } \\
\text { mean of } \\
\text { controls }\end{array}$ & $\begin{array}{l}\text { CRS were classified as eosinophilic when per- } \\
\text { cent eosinophils exceeded twice the SD of the } \\
\text { mean of controls }(4.77 \%+2 \times 2.47 \%=9.71 \%)\end{array}$ \\
\hline $\begin{array}{l}\text { Gao } \\
2016^{(24)}\end{array}$ & China & $\begin{array}{l}153 \text { CRSwNP } \\
\text { (75 e-CRS) }\end{array}$ & $\begin{array}{l}\text { Prospective, Ob- } \\
\text { servational, Cross- } \\
\text { sectional study }\end{array}$ & $\begin{array}{l}>10 \% \text { of the } \\
\text { inflammatory } \\
\text { cells }\end{array}$ & $\begin{array}{l}\text { Median } \\
\text { proportion } \\
\text { of eosinop- } \\
\text { hils }\end{array}$ & $\begin{array}{l}\text { Median proportions of eosinophils and neu- } \\
\text { trophils hovered around } 10 \% \text { of all inflamma- } \\
\text { tory cells (preliminary study) }\end{array}$ \\
\hline $\begin{array}{l}\text { Ikeda } \\
2013^{(44)}\end{array}$ & Japan & $\begin{array}{l}130 \text { CRSwNP } \\
\text { (42 e-CRS and } 88 \\
\text { non-eCRS) }\end{array}$ & $\begin{array}{l}\text { Prospective, } \\
\text { Observational, } \\
\text { Cohort }\end{array}$ & $>100 \mathrm{Eos} / \mathrm{HPF}$ & $\begin{array}{l}\text { Polyps } \\
\text { recurrence }\end{array}$ & $\begin{array}{l}\text { ROC curve (number of patients with polyp } \\
\text { recurrence X number of eosinophils) }\end{array}$ \\
\hline $\begin{array}{l}\text { Jeong } \\
2011^{(40)}\end{array}$ & $\begin{array}{l}\text { South } \\
\text { Korea }\end{array}$ & $\begin{array}{l}118 \text { CRSwNP } \\
\text { (74 e-CRS/ } 44 \\
\text { non-eCRS) }\end{array}$ & $\begin{array}{l}\text { Prospective, } \\
\text { Observational, } \\
\text { Cohort }\end{array}$ & $\begin{array}{l}>11 \% \text { Eos/ } \\
\text { inflammatory } \\
\text { cells }\end{array}$ & $\begin{array}{l}\text { Asthma } \\
\text { and allergy }\end{array}$ & $\begin{array}{l}\text { ROC curve (Number of patients with of asthma } \\
\text { and allergy } X \text { number of eosinophils) }\end{array}$ \\
\hline $\begin{array}{l}\text { Jiang } \\
2011^{(36)}\end{array}$ & China & $\begin{array}{l}42 \text { CRS } \\
10 \text { Controls }\end{array}$ & $\begin{array}{l}\text { Prospective, ob- } \\
\text { servational, cross- } \\
\text { sectional study }\end{array}$ & $\begin{array}{l}>8 \% \text { ratio of eos/ } \\
\text { inflammatory } \\
\text { cells }\end{array}$ & $\begin{array}{l}\text { Twice the } \\
\text { SD of the } \\
\text { mean of } \\
\text { controls }\end{array}$ & $\begin{array}{l}\text { CRS were classified as eosinophilic when per- } \\
\text { cent eosinophils exceeded twice the SD of the } \\
\text { mean of controls }(4.4 \%+2 \times 1.7 \%=7.8 \%)\end{array}$ \\
\hline $\begin{array}{l}\text { Kountakis } \\
2004^{(38)}\end{array}$ & USA & $\begin{array}{l}47 \text { CRS ( } 28 \text { e-CRS } \\
\text { and } 19 \text { non- } \\
\text { eCRS) }\end{array}$ & $\begin{array}{l}\text { Prospective, ob- } \\
\text { servational, cross- } \\
\text { sectional study }\end{array}$ & $>5$ eos/ HPF & $\begin{array}{l}\text { EG2 stained } \\
\text { tissue }\end{array}$ & $\begin{array}{l}\text { All tissue slides with more than five eosinophils/ } \\
\text { HPF stained EG2 and none of the tissue with }<5 \\
\text { eos/HPF stained with EG2. }\end{array}$ \\
\hline $\begin{array}{l}\text { Lou } \\
2015^{(34)}\end{array}$ & China & 387 CRSwNP & $\begin{array}{l}\text { Retrospective } \\
\text { observational, } \\
\text { cross-sectional } \\
\text { study }\end{array}$ & $\begin{array}{l}>27 \% \text { of Eos/ } \\
\text { inflammatory } \\
\text { cells or }>55 \text { eos/ } \\
\text { HPF }\end{array}$ & $\begin{array}{l}\text { Polyps } \\
\text { recurrence }\end{array}$ & $\begin{array}{l}\text { ROC curve (number of patients with polyp } \\
\text { recurrence X number of eosinophils) }\end{array}$ \\
\hline $\begin{array}{l}\text { Lou } \\
2016^{(3)}\end{array}$ & China & 366 CRSwNP & $\begin{array}{l}\text { Retrospective } \\
\text { observational } \\
\text { study with cluster } \\
\text { analysis }\end{array}$ & $\begin{array}{l}\geq 54,5 \% \text { of Eos/ } \\
\text { inflammatory } \\
\text { cells }\end{array}$ & $\begin{array}{l}\text { Cluster } \\
\text { analysis }\end{array}$ & $\begin{array}{l}\text { Cluster analysis ( } 5 \text { clusters Plasma-cells } \\
\text { dominant phenotype; lymphocyte dominant } \\
\text { phenotype; mixed inflammatory phenotype, } \\
\text { neutrophil-dominant phenotype; eosinophil- } \\
\text { dominant phenotype) }\end{array}$ \\
\hline $\begin{array}{l}\text { Nakayama } \\
2011^{(45)}\end{array}$ & Japan & 223 CRS & $\begin{array}{l}\text { Prospective, } \\
\text { observational, lon- } \\
\text { gitudinal study }\end{array}$ & $\geq 70$ eos/HPF & $\begin{array}{l}\text { Polyps } \\
\text { recurrence }\end{array}$ & $\begin{array}{l}\text { ROC curve (number of patients with polyp } \\
\text { recurrence X number of eosinophils) }\end{array}$ \\
\hline $\begin{array}{l}\text { Nakayama } \\
2012^{(12)}\end{array}$ & Japan & 425 CRS & $\begin{array}{l}\text { Retrospective, } \\
\text { observational } \\
\text { study with cluster } \\
\text { analysis }\end{array}$ & $\geq 80.5 \mathrm{eos} / \mathrm{HPF}$ & $\begin{array}{l}\text { Cluster } \\
\text { analysis }\end{array}$ & $\begin{array}{l}\text { Cluster analysis: } 5 \text { factors within } 16 \text { variables } \\
\text { were chosen to perform cluster analysis: Symp- } \\
\text { tom score, Perennial allergy, disease severity } \\
\text { (CT polyp score), Asthma and Eosinophil Count. }\end{array}$ \\
\hline $\begin{array}{l}\text { Soler } \\
2010^{(42)}\end{array}$ & USA & 102 CRS & $\begin{array}{l}\text { Prospective, } \\
\text { observational, lon- } \\
\text { gitudinal study }\end{array}$ & $\geq 10 \mathrm{Eos} / \mathrm{HPF}$ & $\begin{array}{l}\text { Disease- } \\
\text { specific } \\
\text { QOL impro- } \\
\text { vement }\end{array}$ & $\begin{array}{l}6 \text { cut-points were compared including: }>1,>5 \text {, } \\
>10,>50,>100, \text { and }>250 \text { eosinophils/HPF. The } \\
\text { optimal cut-point was the largest absolute dif- } \\
\text { ference in disease-specific QOL change scores } \\
\text { (postoperative minus preoperative) and smal- } \\
\text { lest corresponding p-value. }\end{array}$ \\
\hline $\begin{array}{l}\text { Tokunaga } \\
2015^{(6)}\end{array}$ & Japan & $\begin{array}{l}1716 \text { CRS ( } 672 \\
\text { e-CRS and } 1044 \\
\text { non-eCRS) }\end{array}$ & $\begin{array}{l}\text { Retrospective } \\
\text { multi-centered ob- } \\
\text { servational study }\end{array}$ & $\geq 70$ eos/HPF & $\begin{array}{l}\text { CRS } \\
\text { recurrence }\end{array}$ & $\begin{array}{l}\text { ROC curve (number of patients with polyp } \\
\text { recurrence } X \text { number of eosinophils) }\end{array}$ \\
\hline $\begin{array}{l}\text { Yamada } \\
2019^{(43)}\end{array}$ & Japan & 37 CRS & $\begin{array}{l}\text { Prospective, } \\
\text { observational, lon- } \\
\text { gitudinal study }\end{array}$ & $\geq 55 \mathrm{Eos} / \mathrm{HPF}$ & $\begin{array}{l}\text { CRS } \\
\text { recurrence }\end{array}$ & $\begin{array}{l}\text { ROC curve (number of patients with polyp } \\
\text { recurrence X number of eosinophils) }\end{array}$ \\
\hline
\end{tabular}

CRS: Chronic Rhinosinusitis, e-CRS: Eosinophilic Chronic rhinosinusitis, non-eCRS: Non Eosinophilic Chronic rhinosinusitis, CRSwNP: Chronic rhinosinusitis with nasal polyps, CRSsNP: Chronic rhinosinusitis without nasal polyps, Eos= eosinophils, HPF: High power field, SD: standard deviation, ROC : Receiver Operating Characteristic, QoL: quality of life, CT: computed tomography. 
Table 2. Quality assessment tool for observational cohort and cross-sectional studies.

\begin{tabular}{|c|c|c|c|c|c|c|c|c|c|c|c|c|c|c|c|}
\hline $\begin{array}{l}\text { Author } \\
\text { (year) }\end{array}$ & Q1 & Q2 & Q3 & Q4 & Q5 & Q6 & Q7 & Q8 & Q9 & Q10 & Q11 & Q12 & Q13 & Q14 & $\begin{array}{l}\text { Total } \\
\text { Score }\end{array}$ \\
\hline $\begin{array}{l}\text { Cao } \\
(2009)\end{array}$ & Yes & Yes & NR & Yes & No & NA & NA & NA & NA & NA & Yes & Yes & NA & No & 5 \\
\hline $\begin{array}{l}\text { Gao } \\
(2016)\end{array}$ & Yes & Yes & NR & No & No & NA & NA & NA & NA & NA & Yes & Yes & NA & No & 4 \\
\hline $\begin{array}{l}\text { Ikeda } \\
\text { (2013) }\end{array}$ & Yes & Yes & NR & Yes & No & NA & NA & NA & NA & NA & Yes & NR & NR & Yes & 5 \\
\hline $\begin{array}{l}\text { Jeong } \\
(2011)\end{array}$ & Yes & Yes & NR & Yes & No & NA & NA & NA & NA & NA & Yes & Yes & NR & Yes & 6 \\
\hline $\begin{array}{l}\text { Jiang } \\
(2011)\end{array}$ & Yes & Yes & NR & Yes & No & NA & NA & NA & NA & NA & Yes & Yes & NA & No & 5 \\
\hline $\begin{array}{l}\text { Kountakis } \\
(2004)\end{array}$ & Yes & Yes & NR & Yes & No & NA & NA & NA & NA & NA & Yes & NR & NA & Yes & 5 \\
\hline $\begin{array}{l}\text { Lou } \\
(2015)\end{array}$ & Yes & Yes & NR & Yes & No & NA & NA & NA & NA & NA & Yes & Yes & Yes & Yes & 7 \\
\hline $\begin{array}{l}\text { Lou } \\
(2016)\end{array}$ & Yes & Yes & NR & Yes & No & NA & NA & NA & NA & NA & Yes & Yes & Yes & Yes & 7 \\
\hline $\begin{array}{l}\text { Nakayama } \\
\text { (2011) }\end{array}$ & Yes & Yes & Yes & Yes & No & NA & NA & NA & NA & NA & Yes & Yes & No & Yes & 7 \\
\hline $\begin{array}{l}\text { Nakayana } \\
(2012)\end{array}$ & Yes & Yes & Yes & Yes & No & NA & NA & NA & NA & NA & Yes & Yes & Yes & Yes & 8 \\
\hline $\begin{array}{l}\text { Soler } \\
(2010)\end{array}$ & Yes & Yes & Yes & Yes & No & NA & NA & NA & NA & NA & Yes & Yes & No & No & 6 \\
\hline $\begin{array}{l}\text { Tokunaga } \\
\text { (2015) }\end{array}$ & Yes & Yes & Yes & Yes & Yes & NA & NA & NA & NA & NA & Yes & Yes & NR & Yes & 8 \\
\hline $\begin{array}{l}\text { Yamada } \\
\text { (2019) }\end{array}$ & Yes & Yes & NR & Yes & No & NA & NA & NA & NA & NA & Yes & Yes & No & Yes & 6 \\
\hline
\end{tabular}

$\mathrm{NA}=$ not applicable; $\mathrm{NR}=$ not reported

Questions (Q1-Q14).

1. Was the research question or objective in this paper clearly stated?

2. Was the study population clearly specified and defined?

3. Was the participation rate of eligible persons at least $50 \%$ ?

4. Were all the subjects selected or recruited from the same or similar populations (including the same time period)? Were inclusion and exclusion criteria for being in the study prespecified and applied uniformly to all participants?

5. Was a sample size justification, power description, or variance and effect estimates provided?

6. For the analyses in this paper, were the exposure(s) of interest measured prior to the outcome(s) being measured?

7. Was the timeframe sufficient so that one could reasonably expect to see an association between exposure and outcome if it existed?

8. For exposures that can vary in amount or level, did the study examine different levels of the exposure as related to the outcome (e.g., categories of exposure, or exposure measured as continuous variable)?

9. Were the exposure measures (independent variables) clearly defined, valid, reliable, and implemented consistently across all study participants?

10. Was the exposure(s) assessed more than once over time?

11. Were the outcome measures (dependent variables) clearly defined, valid, reliable, and implemented consistently across all study participants?

12. Were the outcome assessors blinded to the exposure status of participants?

13. Was loss to follow-up after baseline $20 \%$ or less?

14. Were key potential confounding variables measured and adjusted statistically for their impact on the relationship between exposure(s) and outcome(s)? 
than 10\% eos/inflammatory cells, as reported by Cao, $2009^{(14)}$. Patients were divided into 7 clusters. Cluster 1:Type 2 eCRSwNP had a median eosinophil count of $29.5 \%$ eos/inflammatory cells, and had poor treatment outcome, with $50 \%$ of difficult to treat cases.

Kim et al. ${ }^{(15)}$ conducted a retrospective study with 375 CRSwNP patients. When polyp eosinophil count surpassed $20 \%$ of the total inflammatory cells, it was classified as e-CRS as reported by Kim $2013^{(16)}$. Six variables were defined for clustering: Comorbid airway disease, blood eosinophil, tissue eosinophil, Lund-Mackay score (Ethmoid/Maxillary or E/M score), Mean Lund-Mackay score, and age. Four factors were then used, age $\geq 35$, asthma, tissue eosinophilia, and E/M score $\geq 2$.2. Patients were divided in 6 clusters. The clusters with a higher risk of revision surgery were A2 (asthmatic, eosinophilic polyp patients), NA2 (non-asthmatic, non -eosinophilic polyp patients with younger age) and NA4 (non-asthmatic, eosinophilic polyp patients with higher E/M ratio).

\section{Optimal cut-off points for eosinophils}

All the 142 articles were screened for references that justified the cut-off point value together with articles that demonstrated their own methodology for establishing the cutoff value for eosinophilia. A total of 53 different papers were found in this search, and 40 were excluded for the following reasons: use of immunohistochemistry for eosinophil counting, review article, absence of cut-point value, or not having specified or described the reason or methodology to demonstrate the value for eCRS. The remaining 13 articles are summarized in Table 1.

\section{Methodological quality assessment}

The evaluation of methodological quality was performed only in the 13 cut-off studies. The Quality Assessment Tool for Observational and Cross-sectional Cohorts developed by the National Heart, Lung, and Blood Institute (NHLBI) was used in this assessment, with 14 different criteria. The result is presented in Table 2. Two articles were classified as "good" quality, eleven as "fair", and none as having "poor" quality. The most common caveats were the lack of sample size justification, and not describing participation rate of eligible persons or follow-up rate.

We also determined that the use of standard deviation of controls, immunohistochemistry, asthma and allergy, quality of life (QoL) scores had a high risk of bias, while polyp recurrence and combined parameters in cluster analysis had a low risk of bias.

\section{Discussion}

In an era of personalized and precision medicine, endotype driven potential therapies like use of immunobiologics is becoming more and more important. Histopathology, therefore, is a simple but sophisticated method to assist in CRS endotyping $(1,17)$.
The classification of eCRS is in vogue worldwide, and our study demonstrated a divergence in the cut-off point value for eCRS in different countries. Zhang et al. demonstrated in 2008, a higher eosinophilic infiltration in Belgians CRSwNP patients compared to Chinese patients, establishing a division into predominant eCRS in western countries and predominant non-eCRS in eastern countries ${ }^{(18)}$. Although studies suggest that genetic factors contribute to this difference ${ }^{(19,20)}$, it may also have a tendency of growth of CRS in eastern countries (21). We also found that there is a higher threshold on classification of eosinophilic pattern in eastern countries, especially in Japanese studies, which could increase the discrepancy between the prevalence of eCRS between eastern and western countries. Still, most Chinese articles use the relative $>10 \%$ eosinophil count based on Cao et al. ${ }^{(14)}$.

This review exposes a clear lack of standardization in the method of biopsy and histologic evaluation among the articles. Some authors use a subjective classification grading scale of eosinophil infiltration, Gao et al. also showed a positive correlation between objective and subjective classification of NP, however, that can lead to inter-examiners bias and is very difficult to reproduce accurately ${ }^{(22-24)}$. To objectively assess those classifications, Snidvongs et al described a structured histopathology report to uniform CRS evaluation ${ }^{(25)}$.

Thaitrakool et al showed a significant difference in eosinophil count when comparing biopsies of polyp apex and ethmoid mucosa, but no difference was found when comparing polyp pedicle with polyp apex and ethmoid mucosa ${ }^{(26)}$. Most articles did not specify the site of nasal polyp biopsy, and a minority of the studies used ethmoid mucosa as the site of analysis. Sampling at least three sites of mucosa may reduce risk of a false negative eCRS ${ }^{(27)}$. Considering the recommendation of classification both CRSwNP and CRSsNP as eosinophilic or non-eosinophilic (1), ethmoid mucosa biopsy should be contemplated.

The number of different examiners is seemingly non-significant as Bhatthachayya et al. showed a strong interrater and intrarater reliabilities between pathologists. The same researchers demonstrated a significant correlation within the same individual microscope slide of tissue, when searched for the area of the densest cellular infiltrate ${ }^{(28)}$. The use of blinded pathologists is important to reduce risk of bias in a diagnosis test, and although there is not a consensus, most histopathologists assess the densest inflammatory areas. In this context, using a higher number of HPF for eosinophil counts can reduce the bias that the distribution of eosinophils may not be homogenous ${ }^{(26,29)}$.

A great risk of bias may be introduced by the medications used prior to biopsy. Akiyama reported a $15 \%$ chance of false negative diagnosis of eCRS, considering a 70 eos/HPF cut-off point when short-term low dose oral steroids were administered prior to surgery, which can be reduced by collecting multiple polyp samples ${ }^{(27)}$. De Borja Callejas et al. also proved a significant eo- 
sinophil infiltrate decrease after 2 weeks of combined oral and intranasal steroids, and after 10 weeks of only intranasal steroids maintenance ${ }^{(30)}$. Jankowski et al. also demonstrated a reduction of $3 / 4$ of eosinophils infiltration in nasal polyps tissue in patients without asthma after oral steroids, and a $2 / 3$ reduction in patients with asthma and nasal polyps ${ }^{(31)}$.

Interestingly, there was no difference when topical steroids were used alone, which the author attributed to a possible decrease in the activation of eosinophils, rather than a decrease in the number of cells ${ }^{(31)}$. Similarly, Mastruzzo et al. showed no difference in the density of cellular infiltration in NP after topical steroids, however a significant decrease in eosinophils and EG2+ cells ${ }^{(32)}$.

Among all articles, almost $60 \%$ used the absolute count of eosinophils/HPF to classify eCRS instead of using the relative count of eosinophils/inflammatory cells. There is no consensus in the literature about the best method. Absolute count may be simpler for the pathologist, but can also be biased by a low cell density in the high power field ${ }^{(33)}$. Garín et al. demonstrated that both absolute and relative counting methods for quantifying tissue eosinophilia have statistical correlation ${ }^{(33)}$. Lou et al. compared both methods as a predictor for polyp recurrence, and demonstred that the percentage tissue eosinophil was superior to the absolute tissue eosinophil count ${ }^{(34)}$.

Although classification of different eosinophils counts in groups or grades might be interesting as CRS may have a great number of endotypes, this different degree of eosinophils usually has a cut-off point that correlates to clinical eCRS ${ }^{(25,33,35)}$.

Probably the key question concerning a cut-off point for eCRS is the best reference parameter to use as a comparison of the index test threshold of eosinophils. In this study we identified the following parameters used as reference: standard deviation of controls, immunohistochemistry, asthma and allergy, quality of life (QoL) scores, polyp recurrence and combined parameters in cluster analysis.

In normal nasal mucosa, there are none or very few eosinophils ${ }^{(33)}$. Studies that used twice the standard deviation of the mean controls and applied the median proportion of eosinophils, had a cut-off point ranging between 8 and 10\% $(14,24,36)$. Although Wenzel et al. used this method to classify eosinophilic asthma by endobronchial biopsy, we believe that this parameter can introduce a great risk of bias, as the presence of eosinophil may occur in a mixed inflammatory response ${ }^{(3,37)}$.

Kountakis used an eosinophil activation marker (EG2+) as the single parameter of eosinophil cut-off point. This may be biased as high IL-5 response may have negative eosinophil activation marker ${ }^{(38,39)}$.

The use of clinical parameters may have a significant relevance in medical practice. A cut-off point of $11 \%$ was determined when correlating eosinophil infiltration with asthma and allergy ${ }^{(40)}$. A cohort study by Gitomer et al. showed that patients with mild asthma had significantly elevated levels of tissue eosinophils when compared with patients with severe asthma, which can be explained by the increased need for steroids in severe symptomatic patients ${ }^{(41)}$. Kirtsreesakul's findings indicated that there was no association between a positive skin test and eosinophilic infiltration in nasal polyps ${ }^{(23)}$. Snidvongs, using a 10 eos/HPF cut-off point, found no correlation with asthma ${ }^{(25)}$. Moreover, a multicentric study of CRS inflammatory endotypes based on cluster analysis of biomarkers demonstrated that although most Th2 positive biomarkers correlate to clinic asthma, a group of non-asthmatic IL-5 positive endotype was observed (39). Therefore, using allergy and asthma as a reference parameter may introduce bias.

Conventional clinical features of the eCRS phenotype, such as worse symptom and image scores, quality of life outcome and relapse of disease are not automatically good markers for the presence of eosinophilia in the sinus mucosa ${ }^{(25)}$. Soler et al. was cited by many other authors using the $>10$ eos/HPF cut-off point. The presence of this mucosal eosinophilia threshold predicted less improvement in both disease-specific and general QOL after FESS, but the presence of mucosal eosinophilia did not affect QOL for patients with NP, which can be explained by the removal of polyps done during ESS dramatically improving nasal obstruction, contributing to improve quality of life despite of eosinophilia ${ }^{(42)}$. Hence, quality of life in itself may not be a good parameter for classification.

Five studies demonstrating the method for the cut-off point selection used recurrence as main parameter ${ }^{(6,34,43-45)}$. This may be the most relevant parameter for phenotype division and was therefore chosen as a factor of low risk of bias, even though follow-up time for classifying recurrence also varied greatly. All of these studies were from eastern countries, and all restricted use of oral steroids although two did not specified for how long. Ikeda et al detected a 100 eos/HPF cut-off point ${ }^{(44)}$, in a study selecting only CRSwNP. Both Nakayama and Tokunaga identified a 70 eos/HPF cut point ${ }^{(6,45)}$, and Yamada and Lou found 55 eos/ HPF as an optimal cut-off point, although Lou stressed that the relative count of $>27 \%$ was superior to detect recurrence risk ${ }^{(34,43)}$. McHugh et al. accomplished a Meta-analysis with 11 individual studies, all reporting recurring rates in eCRS, and the highest overall sensitivity, and specificity was identified with a cut-off value $>55$ eos/HPF ${ }^{(4)}$. Interestingly, out of the five studies discussed here, only Yamada's was not included in this Metaanalysis, and it also corroborate with the 55 eos/HPF value ${ }^{(4,43)}$. Hypothesis-free cluster analysis is probably the best research tool to evaluate a cut-off point as it considers both clinical and laboratorial features of eCRS ${ }^{(1)}$. In Lou et al., a cut-off point $>54.4 \%$ of eosinophils was defined. Comorbid asthma, FeNo concentration, peripheral eosinophilia, and olfactory dysfunction mirrored tissue eosinophilia across the five clusters. Moreover, high eosinophilic clusters were associated with the highest 
recurrence rate ${ }^{(3)}$. Nakayama et al. found a $>80.4$ eos/HPF cut-off point, after using the following factors: symptom score, perennial allergy, disease severity (CT polyp score), asthma and eosinophil count ${ }^{(12)}$. Although the study did not examined recurrence, this value is close to the 70 eos/HPF demonstrated in a previous study ${ }^{(45)}$.

This review provides a broad overview of the techniques and parameters used for histological classification of CRS. However, it is limited due to the lack of consistency of the studies as well as the methodology used, patient selection and treatment, and the reference criteria used for classification, making it difficult to compare studies. On the other hand, it is possible to highlight the importance of global standardization through multi-center studies to systematize the classification and consequently, treatment of CRS.

\section{Conclusion}

A multicenter international cluster analysis of CRS endotypes is needed to determine a precise cut-off point for eCRS. Recent publications suggest a range of 55- 80 eos/HPF considering polyp recurrence and cluster analysis, which is a greater value than what is usually performed by most researchers. Further- more, methodologic standardization of biopsy and assessment is needed to certify comparable results. Multiple biopsies sites, densest cellular infiltration area examination and oral steroids restriction at least four weeks before sampling are advisable.

\section{Acknowledgements}

The authors thank Ana Paula de Morais e Oliveira for her assistance with search strategy design.

\section{Authorship contribution}

MDCT performed the data collection, study selections, data analysis, data interpretation and drafted the article. MAA was involved with data collection, study selection and data analysis. MGAR reviewed the article and was involved with the conception of the work. MSA performed critical analysis of the article and rewied the article. ES was involved with the conception of the work, data interpretation and made critical analysis of the article. All authors gave final approval of the version to be published.

\section{Conflict of interest}

All authors have no financial disclosures or conflict of interests.

\section{References}

1. Fokkens WJ, Lund VJ, Hopkins C, et al. European Position Paper on Rhinosinusitis and Nasal Polyps 2020. Rhinol J 2020;Suppl 29:1-464.

2. Akdis CA, Bachert C, Cingi $C$, et al Endotypes and phenotypes of chronic rhinosinusitis: A PRACTALL document of the European Academy of Allergy and Clinical Immunology and the American Academy of Allergy, Asthma \&amp; Immunology. Allergy Clin Immunol2013;131(6):1479-90.

3. Lou H, Meng Y, Piao Y, et al. Cellular phenotyping of chronic rhinosinusitis with nasal polyps. Rhinology 2016;54(2):150-9.

4. McHugh T, Snidvongs K, Xie M, Banglawala S, Sommer D. High tissue eosinophilia as a marker to predict recurrence for eosinophilic chronic rhinosinusitis: a systematic review and meta-analysis. Int Forum Allergy Rhinol 2018;8(12):1421-9.

5. Davide R, Chiara R, Giulio P, et al. Predictive markers of long-term recurrence in chronic rhinosinusitis with nasal polyps. Am J Otolaryngol - Head Neck Med Surg 2020;41(1):102286.

6. Tokunaga T, Sakashita M, Haruna T, et al. Novel scoring system and algorithm for classifying chronic rhinosinusitis: The JESREC Study. Allergy Eur J Allergy Clin Immunol 2015;70(8):995-1003.

7. Moher D, Liberati A, Tetzlaff J, et al. Preferred reporting items for systematic reviews and meta-analyses: The PRISMA statement. PLoS Med 2009;6(7).

8. Ouzzani M, Hammady H, Fedorowicz Z,
Elmagarmid A. Rayyan-a web and mobile app for systematic reviews. Syst Rev 2016;5(1).

9. Fokkens WJ, Lund V, Mullol J. European position paper on rhinosinusitis and nasal polyps 2012. Rhinology 2012;50(SUPPL. 23):1-298.

10. National Heart Lung and Blood Quality Assessment Tool for Observational Cohort and Cross-Sectional Studies. 2014; https:// www.nhlbi.nih.gov/health-topics/studyquality-assessment-tools

11. Muniz-Pardos B, Gomez-Bruton A, MatuteLlorente A, et al. Nonspecific Resistance Training and Swimming Performance. J Strength Cond Res 2020; Publish ahead of print.

12. Nakayama T, Asaka D, Yoshikawa M, et al. Identification of chronic rhinosinusitis phenotypes using cluster analysis. Am J Rhinol Allergy 2012;26(3):172-6.

13. Liao B, Liu JX, Li ZY, et al. Multidimensional endotypes of chronic rhinosinusitis and their association with treatment outcomes. Allergy Eur J Allergy Clin Immunol 2018;73(7):1459-69.

14. Cao PP, Li H Bin, Wang BF, et al. Distinct immunopathologic characteristics of various types of chronic rhinosinusitis in adult Chinese. J Allergy Clin Immunol2009;124(3):478-484.

15. Kim JW, Huh G, Rhee CS, et al. Unsupervised cluster analysis of chronic rhinosinusitis with nasal polyp using routinely available clinical markers and its implication in treatment outcomes. Int Forum Allergy Rhinol
2019;9(1):79-86

16. Kim SY, Park JH, Rhee CS, Chung JH, Kim JW. Does eosinophilic inflammation affect the outcome of endoscopic sinus surgery in chronic rhinosinusitis in Koreans? Am J Rhinol Allergy 2013;27(6):166-9.

17. Brescia G, Alessandrini L, Parrino D, Franz L, Barion U, Marioni G. Emerging Contribution of Histopathology to Our Understanding of Chronic Rhinosinusitis Endotypes: Tissue Eosinophil Count and Aggregates. Am J Rhinol Allergy 2020;34(1):122-6.

18. Zhang N, Van Zele T, Perez-Novo C, et al. Different types of T-effector cells orchestrate mucosal inflammation in chronic sinus disease. J Allergy Clin Immunol 2008;122(5):961-8.

19. Mahdavinia M, Suh LA, Carter RG, et al. Increased noneosinophilic nasal polyps in chronic rhinosinusitis in US second-generation Asians suggest genetic regulation of eosinophilia. J Allergy Clin Immunol2015;135(2):576-9.

20. Tikaram A, Prepageran N. Asian nasal polyps: A separate entity? Med J Malaysia 2013;68(6):445-7.

21. Jin J, Chang DY, Kim SH, et al. Role of hypoxia-inducible factor-1a expression in regulatory $T$ cells on nasal polypogenesis. Laryngoscope 2014;124(5):151-9.

22. Arango P, Borish L, Frierson HF, Kountakis SE. Cysteinyl leukotrienes in chronic hyperplastic rhinosinusitis. Otolaryngol - Head Neck Surg 2002;127(6):512-5.

23. Kirtsreesakul V, Atchariyasathian V. Nasal polyposis: Role of allergy on therapeutic 
response of eosinophil- and noneosinophil-dominated inflammation. Am J Rhinol 2006;20(1):95-100.

24. Gao T, Ng CL, Li C, et al. Smoking is an independent association of squamous metaplasia in Chinese nasal polyps. Int Forum Allergy Rhinol 2016;6(1):66-74.

25. Snidvongs K, Lam M, Sacks $R$, et al. Structured histopathology profiling of chronic rhinosinusitis in routine practice. Int Forum Allergy Rhinol 2012;2(5):376-85.

26. Thaitrakool W, Sukswai N, Keelawat S, et al. Histopathology of ethmoid mucosa versus polyp tissue in diagnosing eosinophilic mucin rhinosinusitis. Rhinology 2019;57(1):67-72

27. Akiyama K, Makihara S, Uraguchi K, Samukawa Y, Oka A, Hoshikawa H. Impact of Preoperative Systemic Corticosteroids on the Histology and Diagnosis of Eosinophilic Chronic Rhinosinusitis. Int Arch Allergy Immunol 2019;179(2):81-8.

28. Bhattacharyya N, Vyas DK, Fechner FP, Gliklich RE, Metson R. Tissue Eosinophilia in Chronic Sinusitis. Arch Otolaryngol Neck Surg 2001;127(9):1102.

29. Szucs E, Ravandi S, Goossens A, Beel M Clement PAR. Eosinophilia in the ethmoid mucosa and its relationship to the severity of inflammation in chronic rhinosinusitis. Am J Rhinol 2002;16(3):131-4.

30. De Borja Callejas F, Martínez-Antõn A, Picado C, et al. Corticosteroid treatment regulates mucosal remodeling in chronic rhinosinusitis with nasal polyps. Laryngoscope 2015;125(5):E158-67.

31. Jankowski R, Bouchoua F, Coffinet L, Vignaud JM. Clinical Factors Influencing the Eosinophil Infiltration of Nasal Polyps. Rhinology 2002;40(4):173-8.

32. Mastruzzo C, Greco LR, Nakano K, et al. Impact of intranasal budesonide on immune inflammatory responses and epithelial remodeling in chronic upper airway inflammation. J Allergy Clin Immuno 2003;112(1):37-44.

33. Garín L, Armengot M, Ramón Alba J, Carda C. Correlations Between Clinical and Histological Aspects in Nasal Polyposis. Acta Otorrinolaringol 2008;59(7):315-20.

34. Lou H, Meng Y, Piao Y, Wang C, Zhang L, Bachert C. Predictive significance of tissue eosinophilia for nasal polyp recurrence in the Chinese population. Am J Rhinol Allergy 2015;29(5):350-6.

35. Grgić MV, Ćupić H, Kalogjera L, Baudoin T. Surgical treatment for nasal polyposis: predictors of outcome. Eur Arch Oto-RhinoLaryngology 2015;272(12):3735-43.

36. Jiang XD, Li GY, Li L, Dong Z, Zhu DD The characterization of IL-17A expression in patients with chronic rhinosinusitis with nasal polyps. Am J Rhinol Allergy 2011;25(5):171-5.

37. Wenzel SE, Schwartz LB, Langmack EL, et al. Evidence that severe asthma can be divided pathologically into two inflammatory subtypes with distinct physiologic and clinical characteristics. Am J Respir Crit Care Med 1999;160(3):1001-8.

38. Kountakis SE, Arango P, Bradley D, Wade ZK, Borish L. Molecular and Cellular Staging for the Severity of Chronic Rhinosinusitis. Laryngoscope 2004;114(11):1895-905.

39. Tomassen P, Vandeplas G, Van Zele T, et al. Inflammatory endotypes of chronic rhinosinusitis based on cluster analysis of biomarkers. J Allergy Clin Immunol 2016;137(5):1449-1456.e4.

40. Jeong WJ, Lee $\mathrm{CH}$, Cho SH, Rhee CS Eosinophilic allergic polyp: A clinically oriented concept of nasal polyp. Otolaryngol - Head Neck Surg 2011;144(2):241-6.

41. Gitomer SA, Fountain CR, Kingdom TT, et al.
Clinical Examination of Tissue Eosinophilia in Patients with Chronic Rhinosinusitis and Nasal Polyposis. Otolaryngol - Head Neck Surg 2016;155(1):173-8.

42. Soler ZM, Sauer D, Mace J, Smith TL. Impact of Mucosal Eosinophilia and Nasal Polyposis on Quality-of-Life Outcomes after Sinus Surgery. Otolaryngol Neck Surg 2010;142(1):64-71.

43. Yamada T, Miyabe $Y$, Ueki S, et al. Eotaxin-3 as a plasma biomarker for mucosal eosinophil infiltration in chronic rhinosinusitis. Front Immunol 2019;10:1-9.

44. Ikeda K, Shiozawa A, Ono N, et al. Subclassification of chronic rhinosinusitis with nasal polyp based on eosinophil and neutrophil. Laryngoscope 2013;123(11):1-9.

45. Nakayama T, Yoshikawa M, Asaka D, et al. Mucosal eosinophilia and recurrence of nasal polyps - new classification of chronic rhinosinusitis. Rhinology 2011;49(4):3.

\author{
Mariana Dalbo Contrera Toro \\ Department of Ophthalmology and \\ Otorhinolaryngology \\ University of Campinas (Unicamp) \\ Faculty of Medical Sciences \\ Campinas \\ São Paulo \\ Brazil
}

Tel: +55 1935217523

E-mail: mdctoro@gmail.com 


\section{Appendix}

Appendix 1.

\begin{tabular}{|c|c|c|c|}
\hline Source & Strategy & $\mathrm{N}^{\circ}$ of studies & Date \\
\hline PUBMED & $\begin{array}{l}\text { ((((Nasal Polyps[MeSH Terms]) OR ("Nasal Polyps"[Title/Abstract] OR "Nasal Polyp"[Title/ } \\
\text { Abstract] OR "Polyp, Nasal"[Title/Abstract] OR "Polyps, Nasal"[Title/Abstract]))) AND } \\
\text { ((Sinusitis[MeSH Terms]) OR (Sinusitis[Title/Abstract] OR Sinusitides[Title/Abstract] OR "Sinus } \\
\text { Infections"[Title/Abstract] OR "Infection, Sinus"[Title/Abstract] OR "Infections, Sinus"[Title/ } \\
\text { Abstract] OR "Sinus Infection"[Title/Abstract]))) AND ((Eosinophils[MeSH Terms]) OR } \\
\text { (Eosinophils[Title/Abstract] OR Eosinophil[Title/Abstract])) }\end{array}$ & 556 & $20 / 01 / 2020$ \\
\hline $\begin{array}{l}\text { PUBMED } \\
\text { PMC }\end{array}$ & $\begin{array}{l}\text { ((((Nasal Polyps[MeSH Terms]) OR ("Nasal Polyps"[Title/Abstract] OR "Nasal Polyp"[Title/ } \\
\text { Abstract] OR "Polyp, Nasal"[Title/Abstract] OR "Polyps, Nasal"[Title/Abstract]))) AND } \\
\text { ((Sinusitis[MeSH Terms]) OR (Sinusitis[Title/Abstract] OR Sinusitides[Title/Abstract] OR "Sinus } \\
\text { Infections"[Title/Abstract] OR "Infection, Sinus"[Title/Abstract] OR "Infections, Sinus"[Title/ } \\
\text { Abstract] OR "Sinus Infection"[Title/Abstract]))) AND ((Eosinophils[MeSH Terms]) OR } \\
\text { (Eosinophils[Title/Abstract] OR Eosinophil[Title/Abstract])) }\end{array}$ & 24 & $20 / 01 / 2020$ \\
\hline $\begin{array}{l}\text { BVS / BIREME } \\
\text { MEDLINE (430) } \\
\text { IBECS (2) } \\
\text { LILACS (1) }\end{array}$ & $\begin{array}{l}\text { tw:((tw:("Nasal Polyps" OR "Pólipos Nasales" OR "Pólipos Nasais")) AND (tw:(sinusitis OR sinu- } \\
\text { sitis OR sinusite)) AND (tw:(eosinophils OR eosinófilos OR eosinófilos))) }\end{array}$ & 432 & $20 / 01 / 2020$ \\
\hline SCOPUS & $\begin{array}{l}\text { (TITLE-ABS-KEY ( "Nasal Polyps" OR "Nasal Polyp" OR "Polyp, Nasal" OR "Polyps, Nasal" ) } \\
\text { AND TITLE-ABS-KEY ( sinusitis OR sinusitides OR "Sinus Infections" OR "Infection, Sinus" } \\
\text { OR "Infections, Sinus" OR "Sinus Infection") AND TITLE-ABS-KEY ( eosinophils OR eosinop- } \\
\text { hil )) }\end{array}$ & 651 & $20 / 01 / 2020$ \\
\hline $\begin{array}{l}\text { WEB OF SCl- } \\
\text { ENCE }\end{array}$ & $\begin{array}{l}\text { TÓPICO: ("Nasal Polyps" OR "Nasal Polyp" OR "Polyp, Nasal" OR "Polyps, Nasal") AND TÓPICO: } \\
\text { (Sinusitis OR Sinusitides OR "Sinus Infections" OR "Infection, Sinus" OR "Infections, Sinus" OR } \\
\text { "Sinus Infection") AND TÓPICO: (Eosinophils OR Eosinophil) } \\
\text { Tempo estipulado: Todos os anos. Índices: SCI-EXPANDED, SSCI, A\&HCI, CPCI-S, CPCI-SSH, } \\
\text { ESCI. }\end{array}$ & 277 & $20 / 01 / 2020$ \\
\hline EMBASE & $\begin{array}{l}\text { ('nose polyp'/exp OR 'nose polyp'/syn) AND ('sinusitis'/exp OR 'sinusitis'/syn) AND ('eosinop- } \\
\text { hil'/exp OR 'eosinophil'/syn) AND [embase]/lim NOT ([embase]/lim AND [medline]/lim) }\end{array}$ & 386 & $20 / 01 / 2020$ \\
\hline $\begin{array}{l}\text { COCHRANE } \\
\text { LIBRARY }\end{array}$ & $\begin{array}{l}\text { MeSH descriptor: [Nasal Polyps] explode all trees OR ("Nasal Polyps" OR "Nasal Polyp" OR } \\
\text { "Polyp, Nasal" OR "Polyps, Nasal"):ti,ab,kw AND MeSH descriptor: [Sinusitis] explode all trees } \\
\text { OR (Sinusitis OR Sinusitides OR "Sinus Infections" OR "Infection, Sinus" OR "Infections, Sinus" } \\
\text { OR "Sinus Infection"):ti,ab,kw AND MeSH descriptor: [Eosinophils] explode all trees OR (Eosi- } \\
\text { nophils OR Eosinophil):ti,ab,kw }\end{array}$ & 55 & $20 / 01 / 2020$ \\
\hline PROQUEST & $\begin{array}{l}\text { ((MJMESH.EXACT.EXPLODE("Nasal Polyps:C.08.460.572") OR MJMESH.EXACT.EXPLODE("Nasal } \\
\text { Polyps:C.09.603.557") OR MJMESH.EXACT.EXPLODE("Nasal Polyps:C.23.300.825.557")) OR } \\
\text { ("Nasal Polyps" OR "Nasal Polyp" OR "Polyp, Nasal" OR "Polyps, Nasal")) AND ((MJMESH.EXACT. } \\
\text { EXPLODE("Sinusitis:C.01.748.749") OR MJMESH.EXACT.EXPLODE("Sinusitis:C.08.460.692.752") } \\
\text { OR MJMESH.EXACT.EXPLODE("Sinusitis:C.08.730.749") OR MJMESH.EXACT.EXPLODE("Sinusit } \\
\text { is:C.09.603.692.752")) OR (Sinusitis OR Sinusitides OR "Sinus Infections" OR "Infection, Sinus" } \\
\text { OR "Infections, Sinus" OR "Sinus Infection")) AND ((MJMESH.EXACT.EXPLODE("eosinophil } \\
\text { :A.15.145.229.637.415.345") OR MJMESH.EXACT.EXPLODE("eosinophil:A.15.382.490.315.251") } \\
\text { OR MJMESH.EXACT.EXPLODE("eosinophil:A.11.627.340.345") OR MJMESH.EXACT.EXPLODE("e } \\
\text { osinophil:A.11.118.637.415.345")) OR (eosinophil OR Eosinophil)) }\end{array}$ & 466 & $20 / 01 / 2020$ \\
\hline TOTAL & & 2847 & \\
\hline $\begin{array}{l}\text { TOTAL OF } \\
\text { DUPLICITIES }\end{array}$ & $\begin{array}{l}1215 \text { STUDIES EXCLUDED WITH ENDNOTE } \\
85 \text { STUDIES EXCLUDED WITH RAYYAN }\end{array}$ & 1300 & \\
\hline $\begin{array}{l}\text { TOTAL AFTER } \\
\text { DUPLICITY } \\
\text { EXCLUSION }\end{array}$ & & 1547 & \\
\hline
\end{tabular}




\begin{tabular}{|c|c|c|c|c|c|c|c|c|c|c|c|c|c|}
\hline 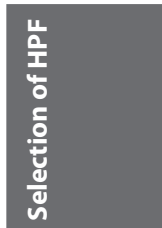 & 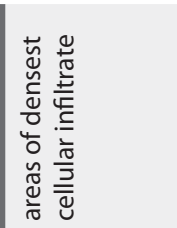 & 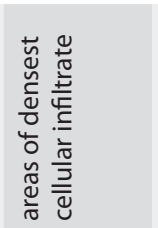 & 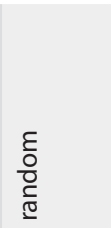 & 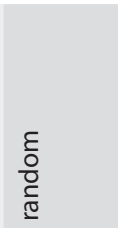 & 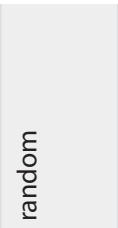 & 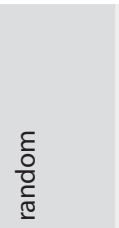 & $\frac{\mathscr{c}}{z}$ & 管 & 孚 & $\frac{\stackrel{⿰}{z}}{z}$ & $\frac{⿱}{z}$ & $\frac{x}{z}$ & $\frac{x}{z}$ \\
\hline$\frac{0}{2}$ & $m$ & - & in & in & in & in & $\frac{⿱}{z}$ & 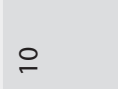 & 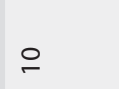 & $m$ & $m$ & $m$ & $m$ \\
\hline 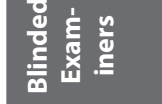 & $\frac{\mathscr{c}}{z}$ & $\frac{\mathscr{c}}{z}$ & $\stackrel{\tilde{\nu}}{\check{\nu}}$ & $\stackrel{\check{x}}{\check{\Perp}}$ & $\stackrel{\check{\nu}}{\check{\nu}}$ & $\stackrel{\breve{\nu}}{\rightleftharpoons}$ & $\stackrel{\breve{x}}{\check{x}}$ & $\frac{\kappa}{z}$ & $\frac{\kappa}{z}$ & $\frac{\kappa}{z}$ & $\frac{\kappa}{z}$ & $\frac{⿱ x}{z}$ & $\frac{x}{z}$ \\
\hline & $\frac{\varrho}{z}$ & $m$ & $\dot{\sim}$ & $N$ & $\sim$ & $\sim$ & $\frac{\mathscr{c}}{z}$ & $\stackrel{\frac{c}{z}}{2}$ & $\frac{\mathscr{c}}{z}$ & $\frac{\mathscr{c}}{z}$ & $\frac{\mathscr{c}}{z}$ & $\frac{\mathscr{c}}{z}$ & $\frac{\mathscr{q}}{z}$ \\
\hline 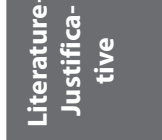 & 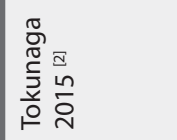 & 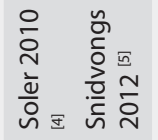 & 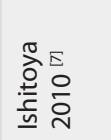 & 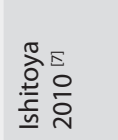 & 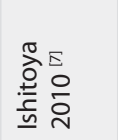 & 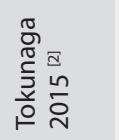 & 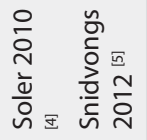 & 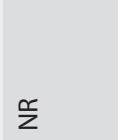 & $\frac{\kappa}{z}$ & $\frac{\kappa}{z}$ & 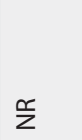 & $\frac{\mathscr{c}}{z}$ & $\frac{\mathscr{c}}{z}$ \\
\hline 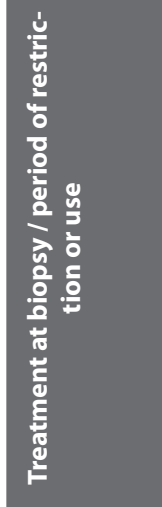 & 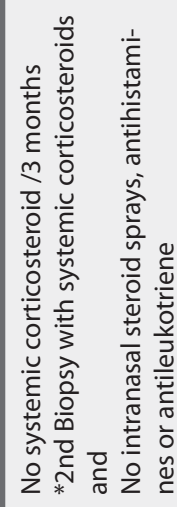 & 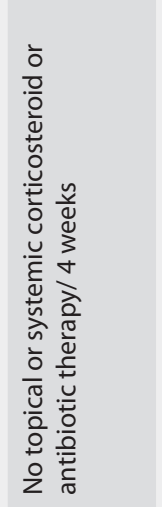 & 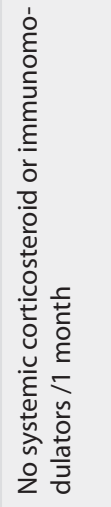 & 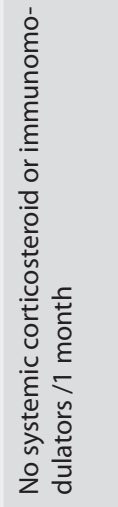 & 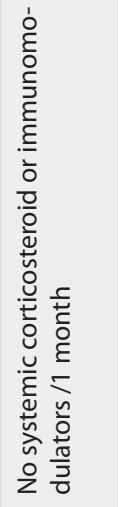 & 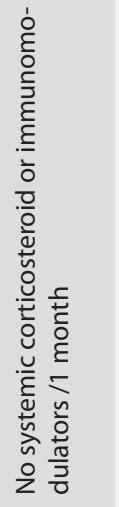 & 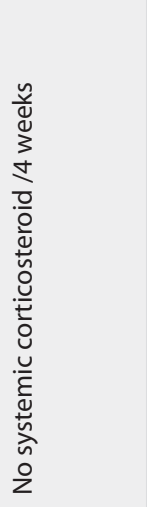 & $\stackrel{\frac{c}{z}}{z}$ & $\stackrel{\frac{c}{z}}{Z}$ & 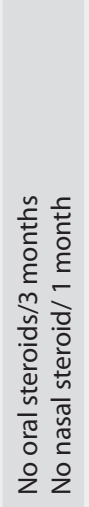 & 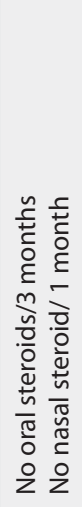 & 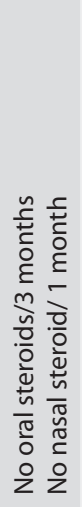 & 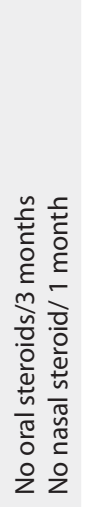 \\
\hline 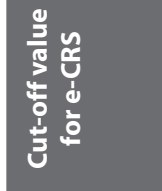 & 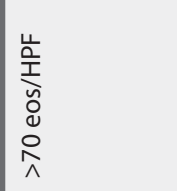 & 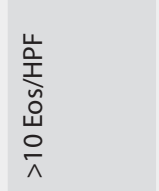 & 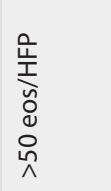 & 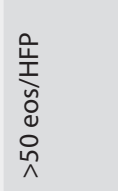 & 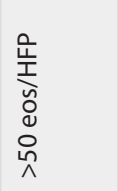 & 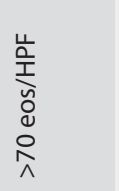 & 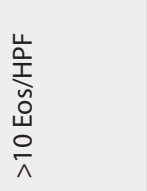 & & 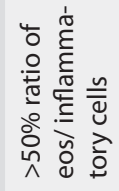 & 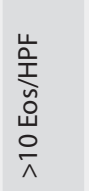 & 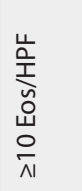 & 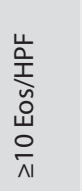 & 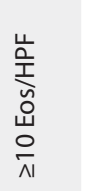 \\
\hline 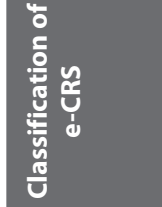 & 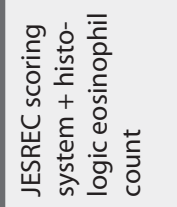 & 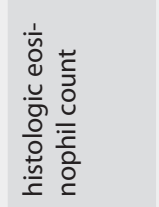 & 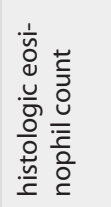 & 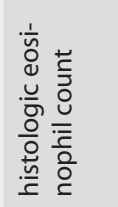 & 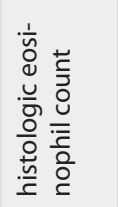 & 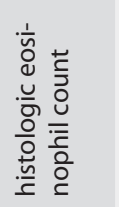 & 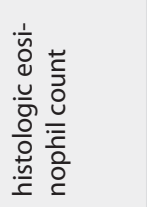 & 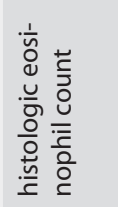 & 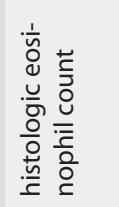 & 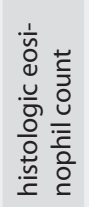 & 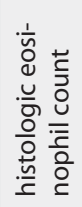 & 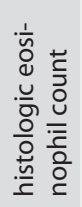 & 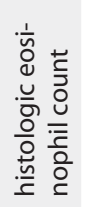 \\
\hline ब㺼 & 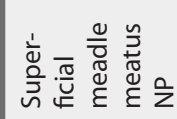 & $\frac{\Upsilon}{z}$ & $\frac{2}{\frac{2}{2}}$ & $\frac{n}{\frac{n}{2}}$ & $\frac{0}{2}$ & $\frac{n}{\frac{0}{2}}$ & $\frac{0}{\frac{0}{2}}$ & 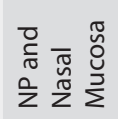 & $\frac{n}{z}$ & $\frac{\kappa}{z}$ & $\frac{\hat{z}}{2}$ & $\frac{\mathscr{c}}{z}$ & $\frac{x}{z}$ \\
\hline 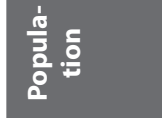 & 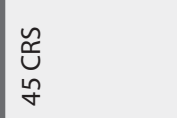 & $\underset{\tilde{N}}{\tilde{N}}$ & 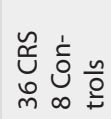 & 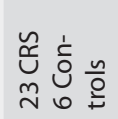 & 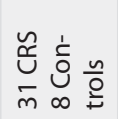 & 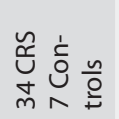 & $\begin{array}{l}\text { 今̛ } \\
\text { ٌे }\end{array}$ & 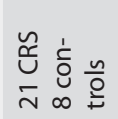 & 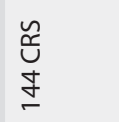 & $\begin{array}{l}\widetilde{\tilde{Z}} \\
\tilde{\tilde{\vartheta}}\end{array}$ & \begin{tabular}{l}
$\widetilde{\widetilde{U}}$ \\
\multirow{+}{\Sigma}{}
\end{tabular} & $\begin{array}{l}\widetilde{\tilde{U}} \\
\stackrel{n}{=}\end{array}$ & \begin{tabular}{l}
$\widetilde{̃}$ \\
\multirow{\Omega}{\alpha}{}
\end{tabular} \\
\hline & & $a$ & e & $a$ & $a$ & a & $\propto$ & $a$ & $a$ & $a$ & $a$ & $\propto$ & $\propto$ \\
\hline 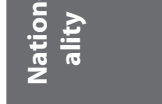 & $\begin{array}{l}\frac{\sqrt{0}}{0} \\
\frac{2}{\pi} \\
\frac{0}{7}\end{array}$ & $\begin{array}{l}\text { बे } \\
\text { 产 }\end{array}$ & 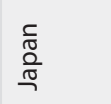 & 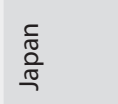 & 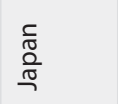 & $\begin{array}{l}\frac{\pi}{0} \\
\frac{0}{9}\end{array}$ & $\frac{0}{\frac{0}{5}}$ & 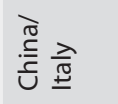 & 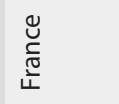 & 离 & $\overline{\underline{\mathbb{N}}}$ & 를 & $\stackrel{\widehat{\bar{\Xi}}}{\underline{\underline{N}}}$ \\
\hline 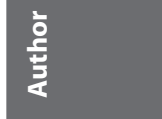 & 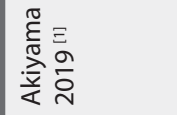 & 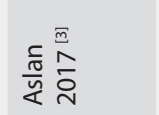 & 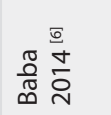 & 总 & 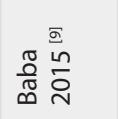 & 离 & 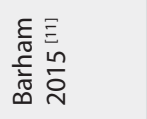 & 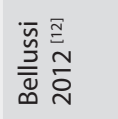 & 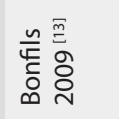 & 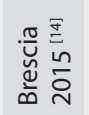 & 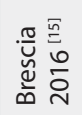 & 离 & 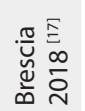 \\
\hline
\end{tabular}




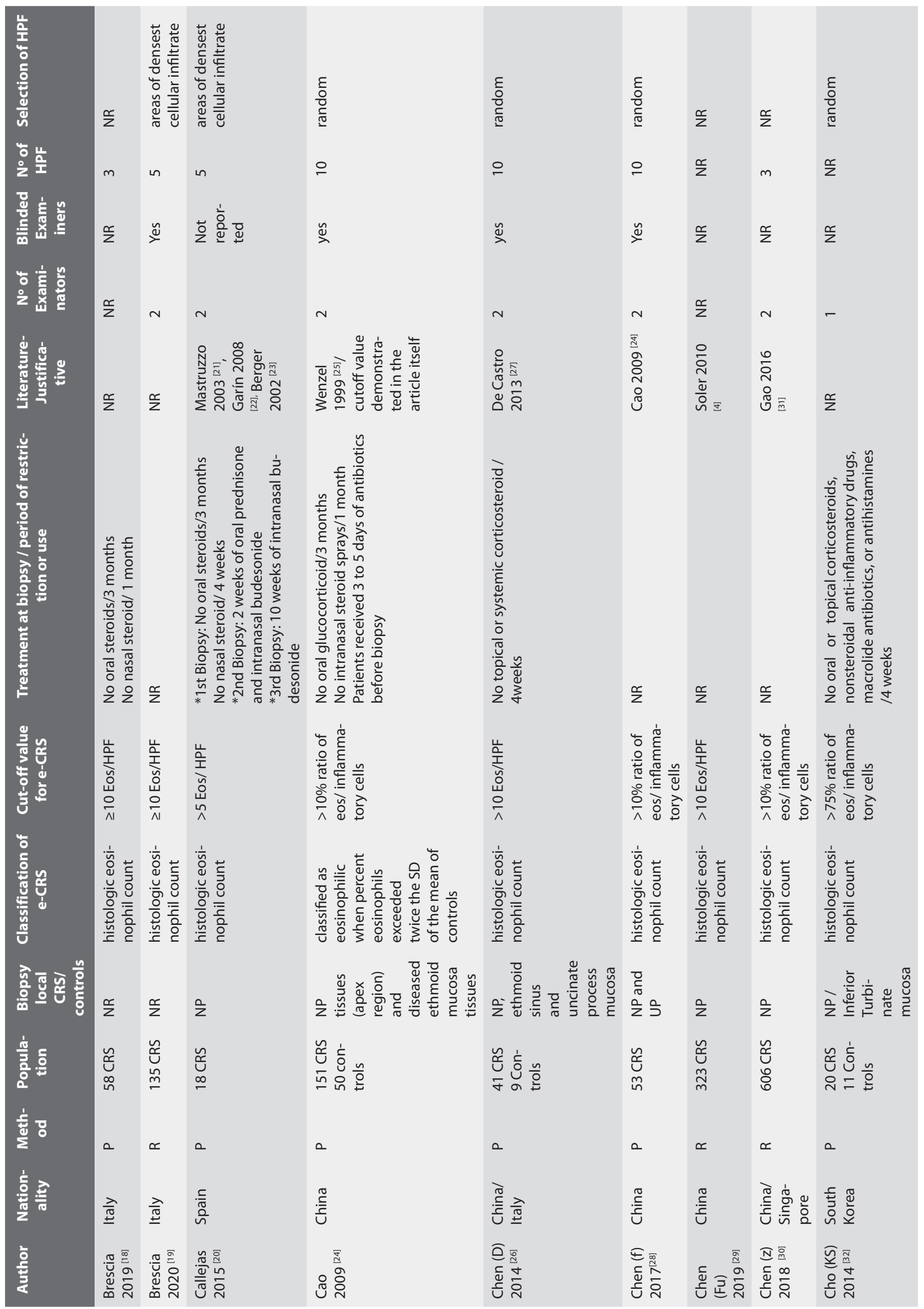




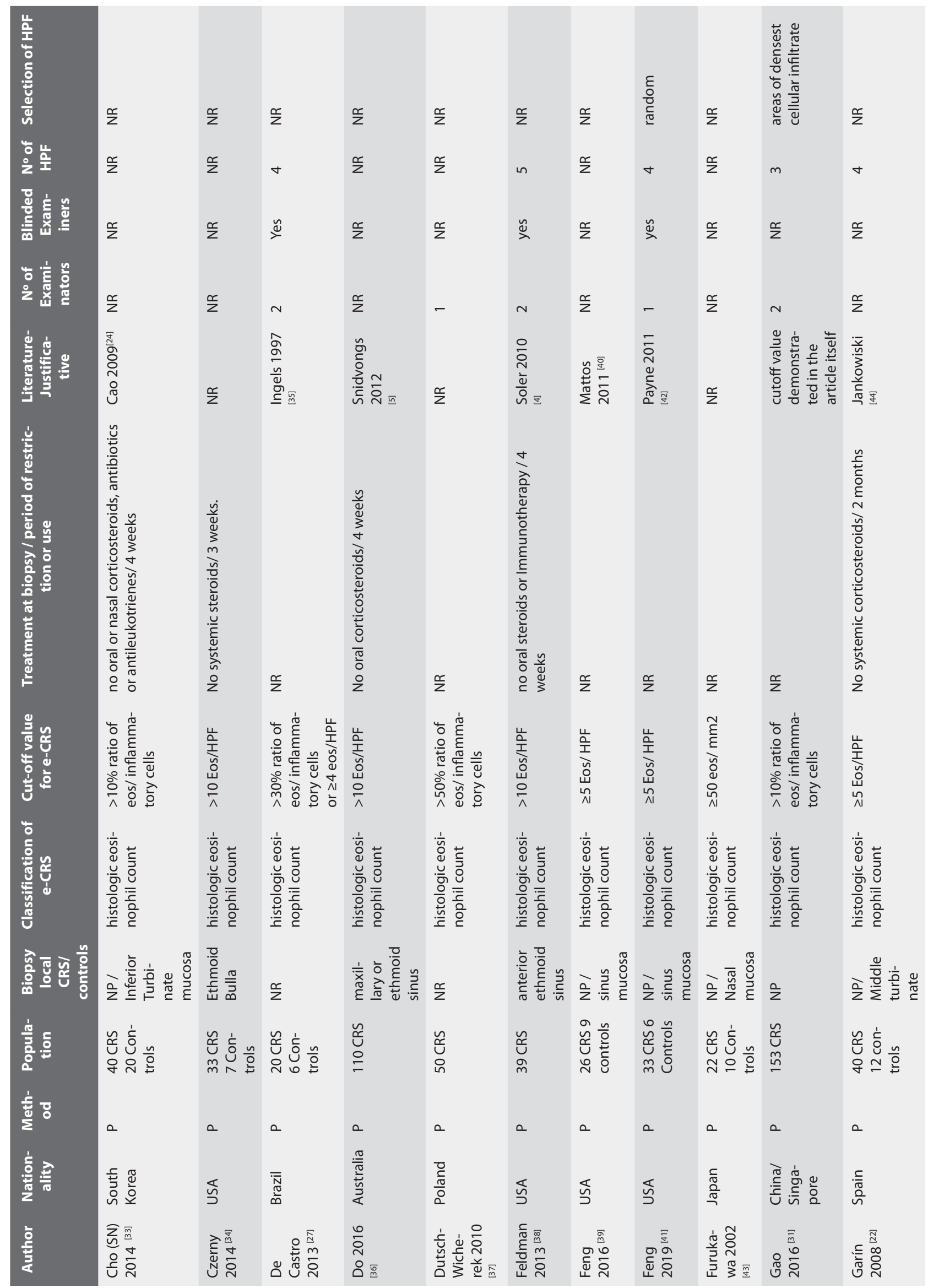




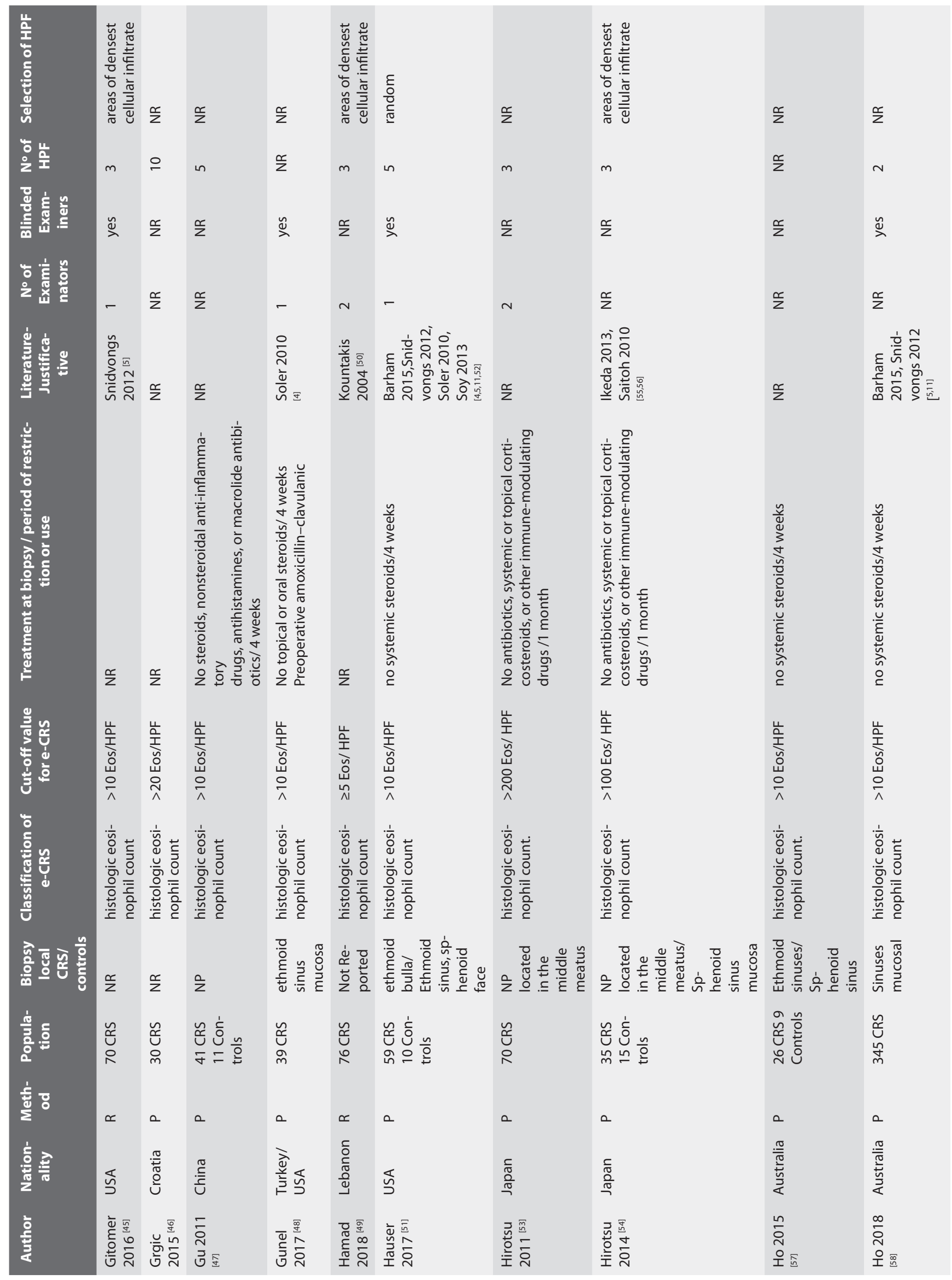




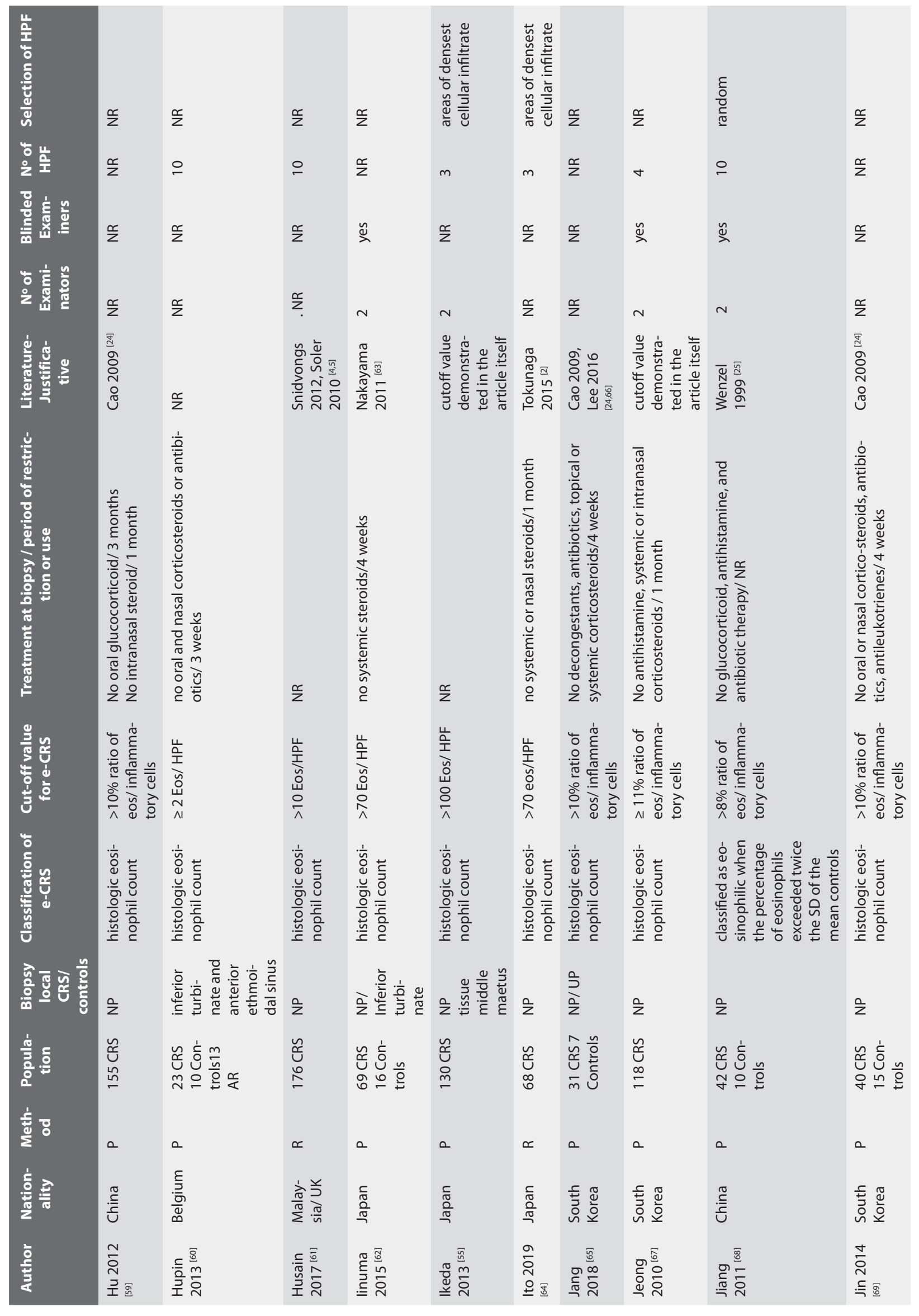




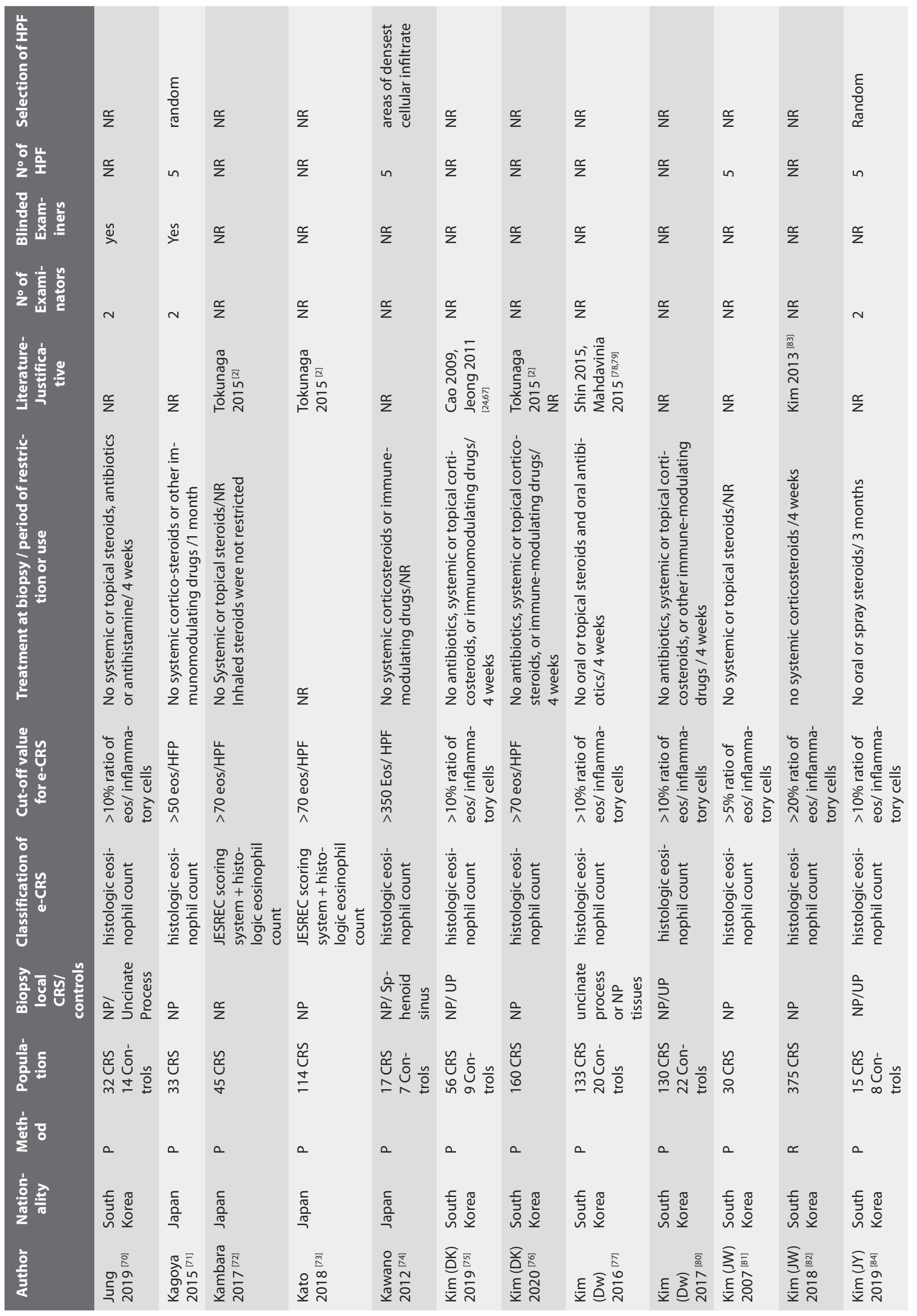




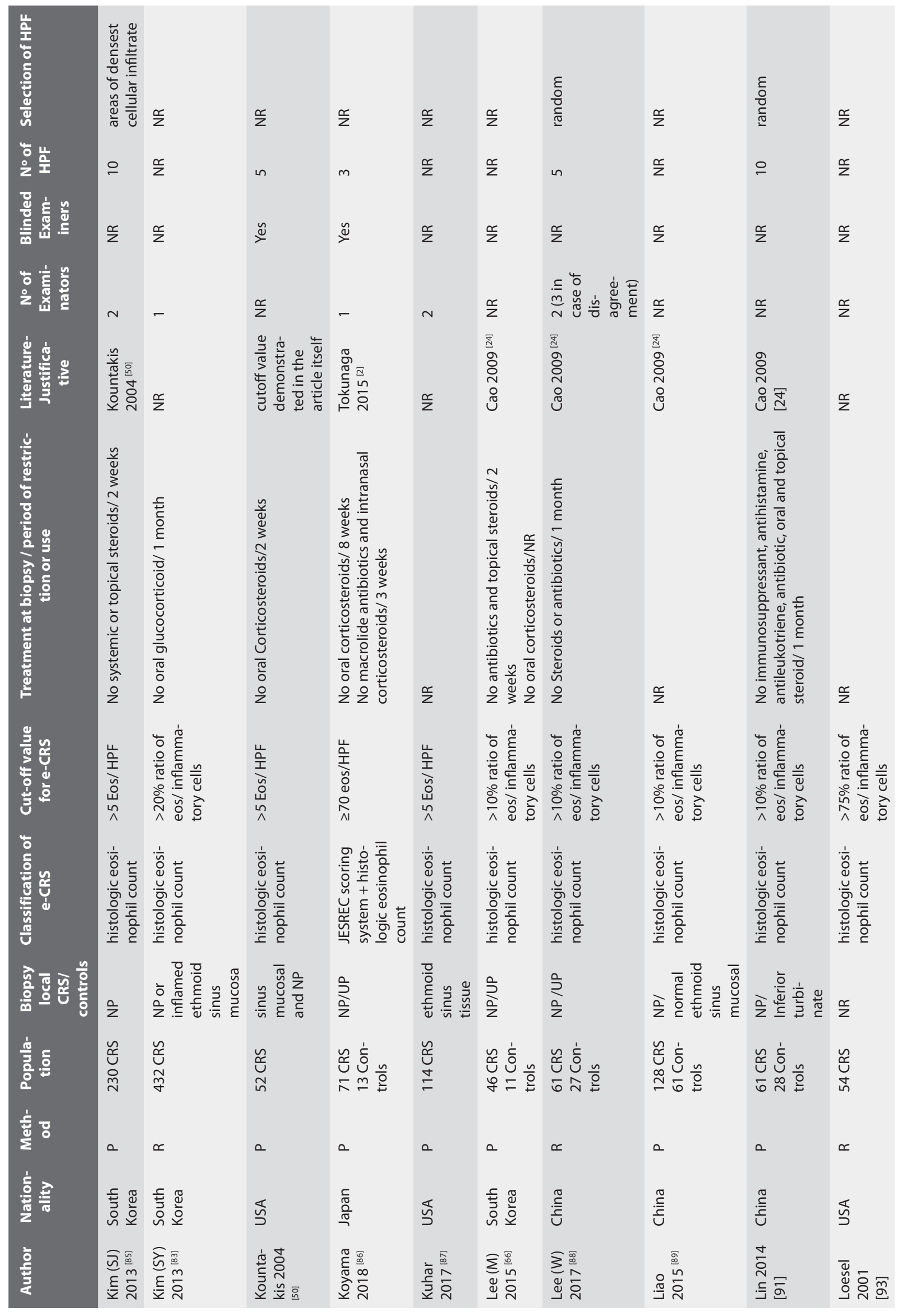




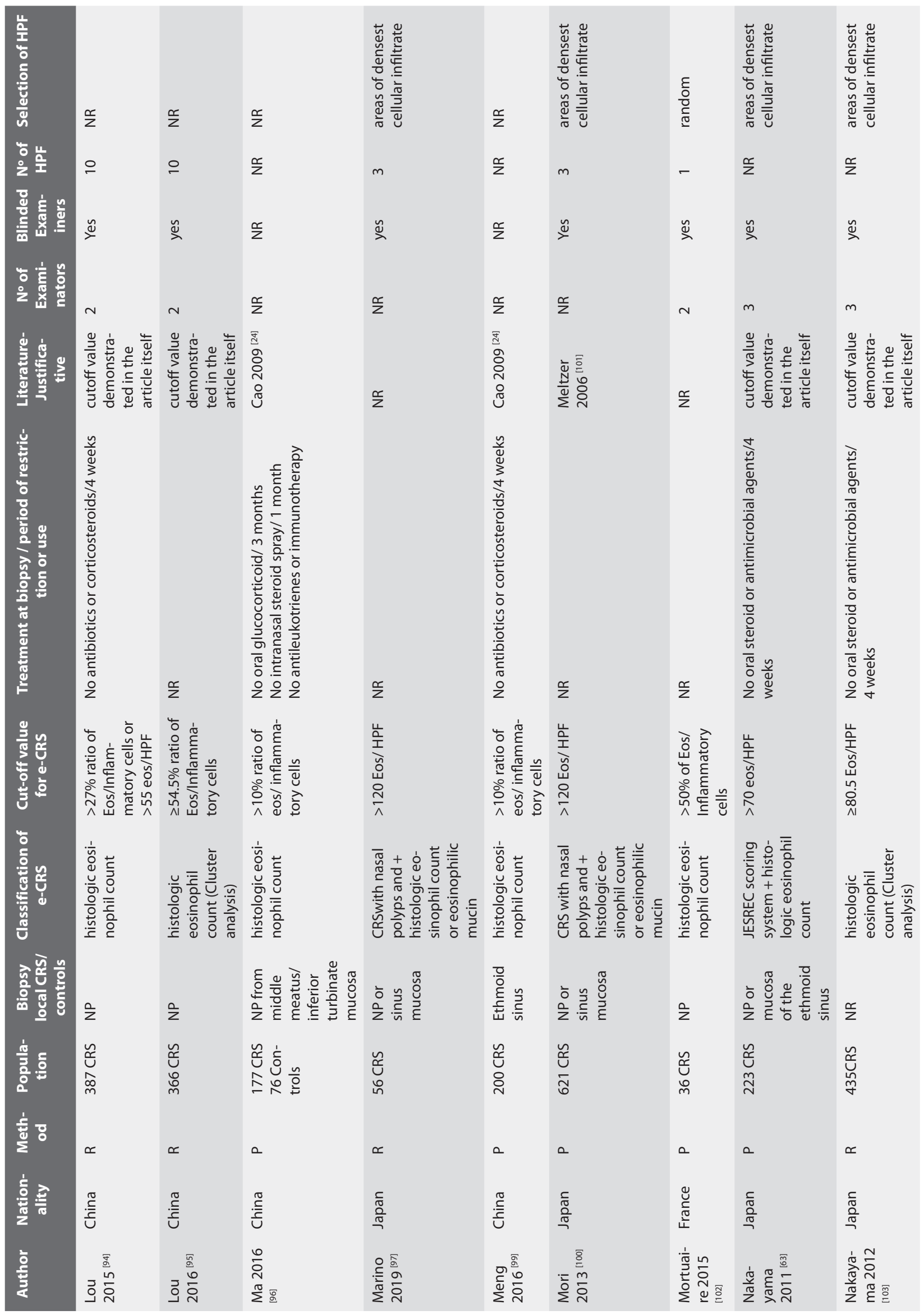




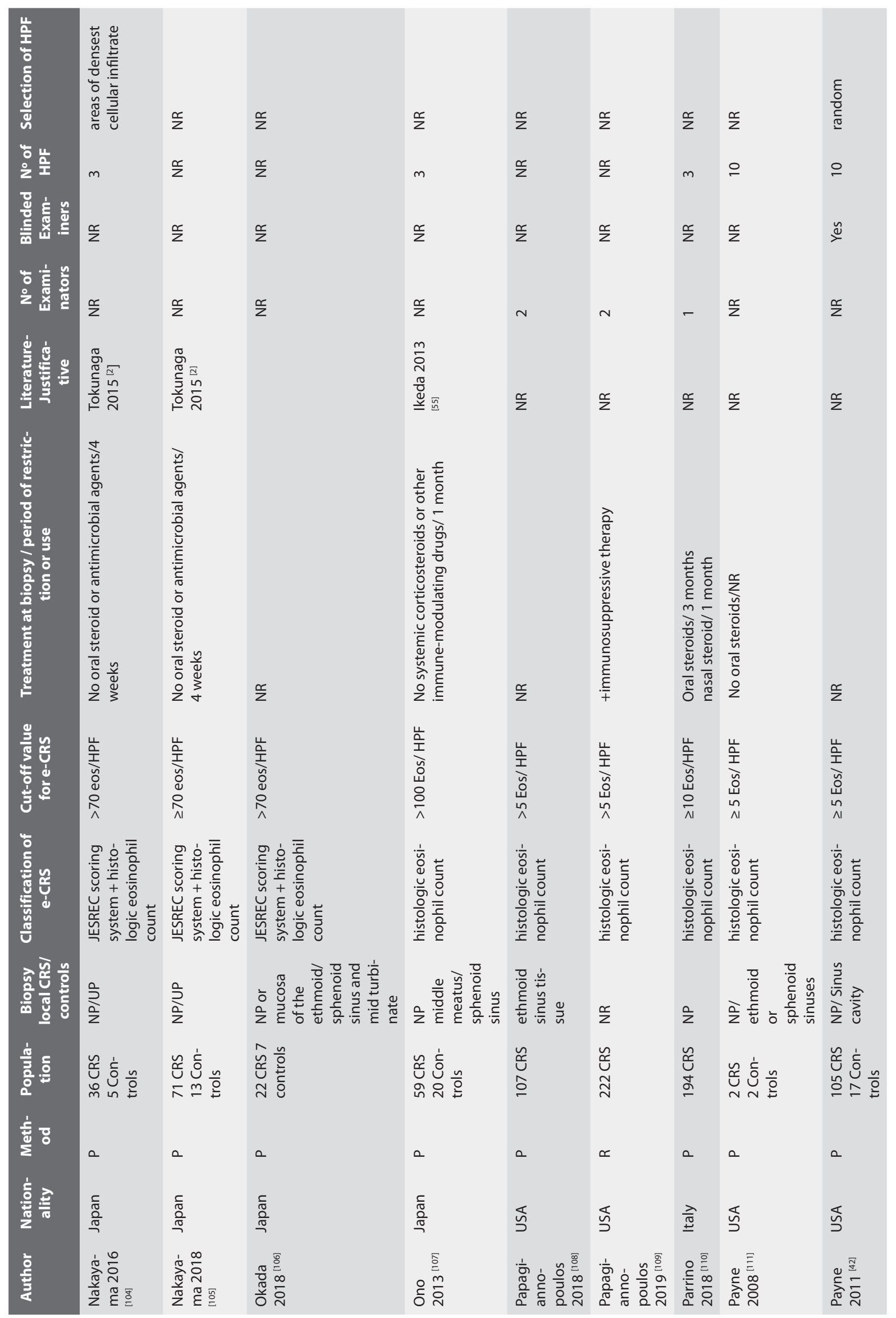




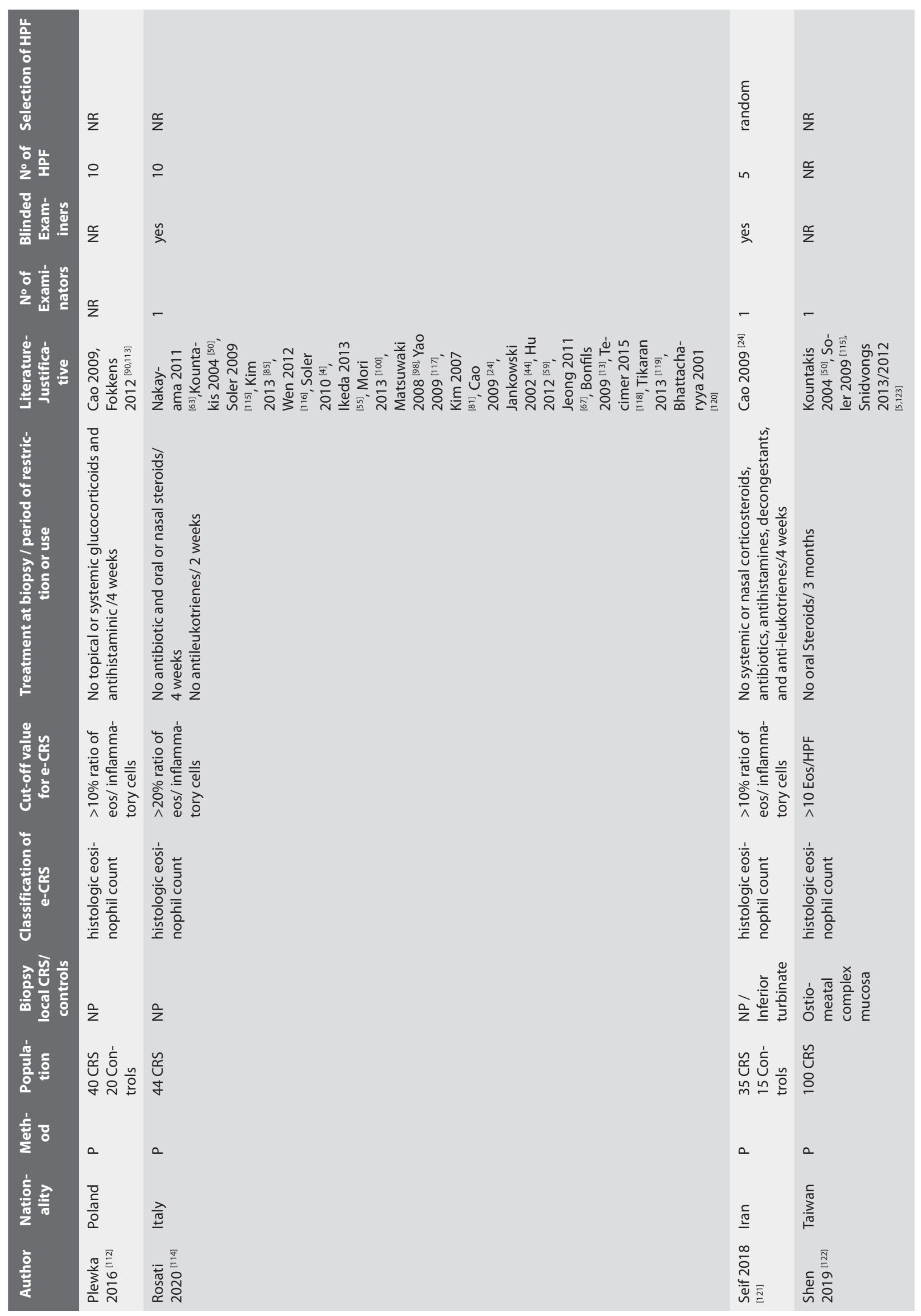




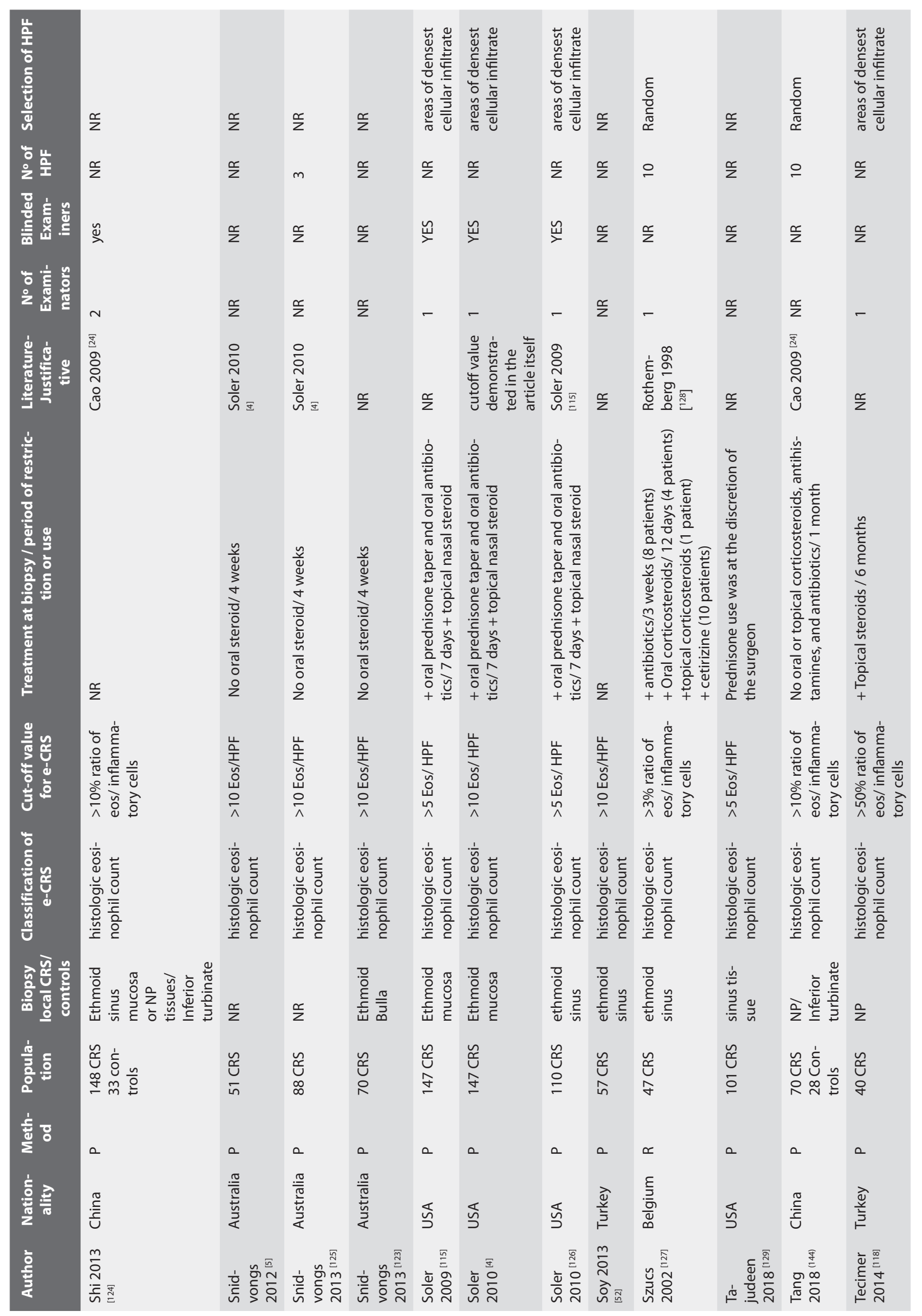




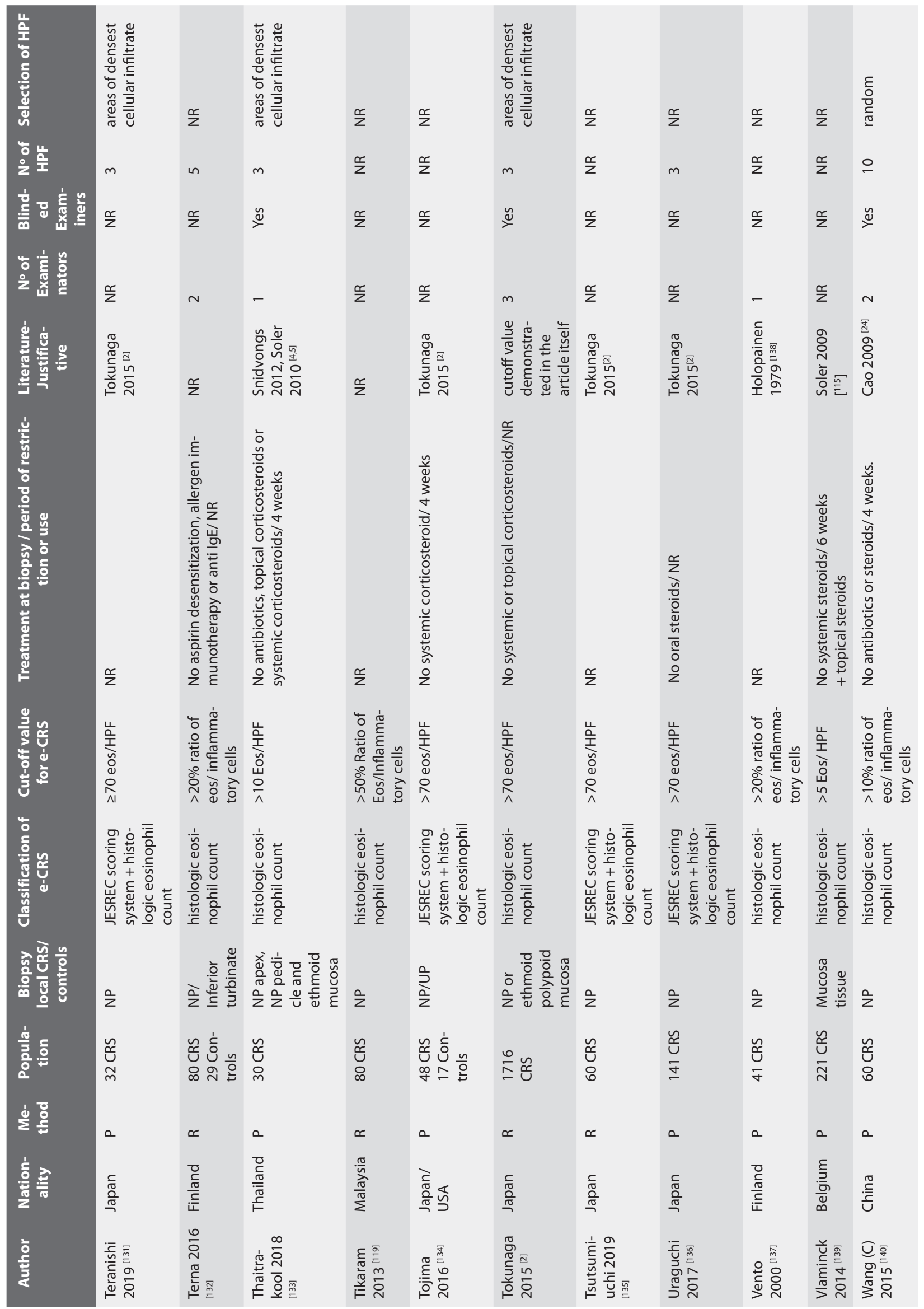




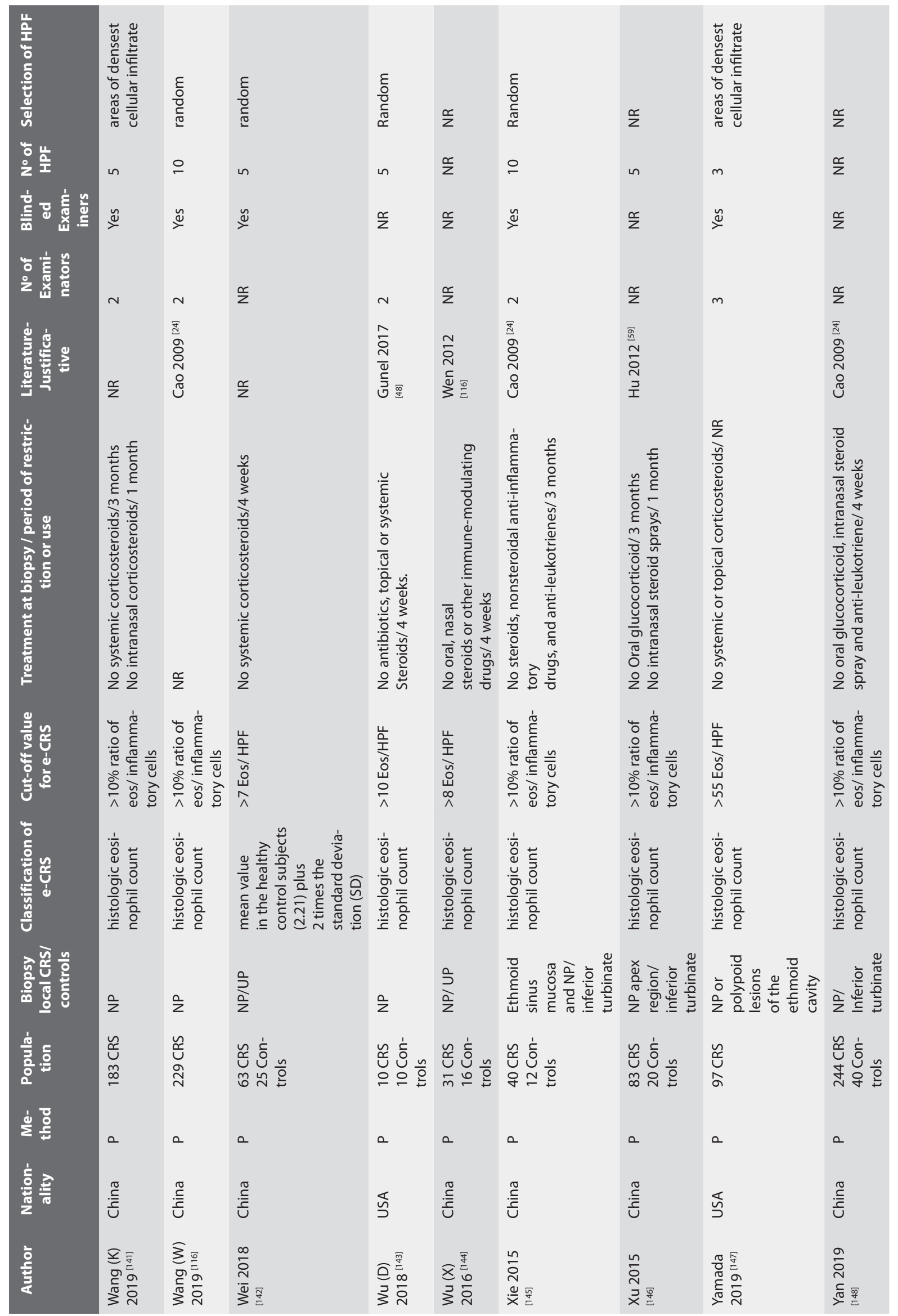




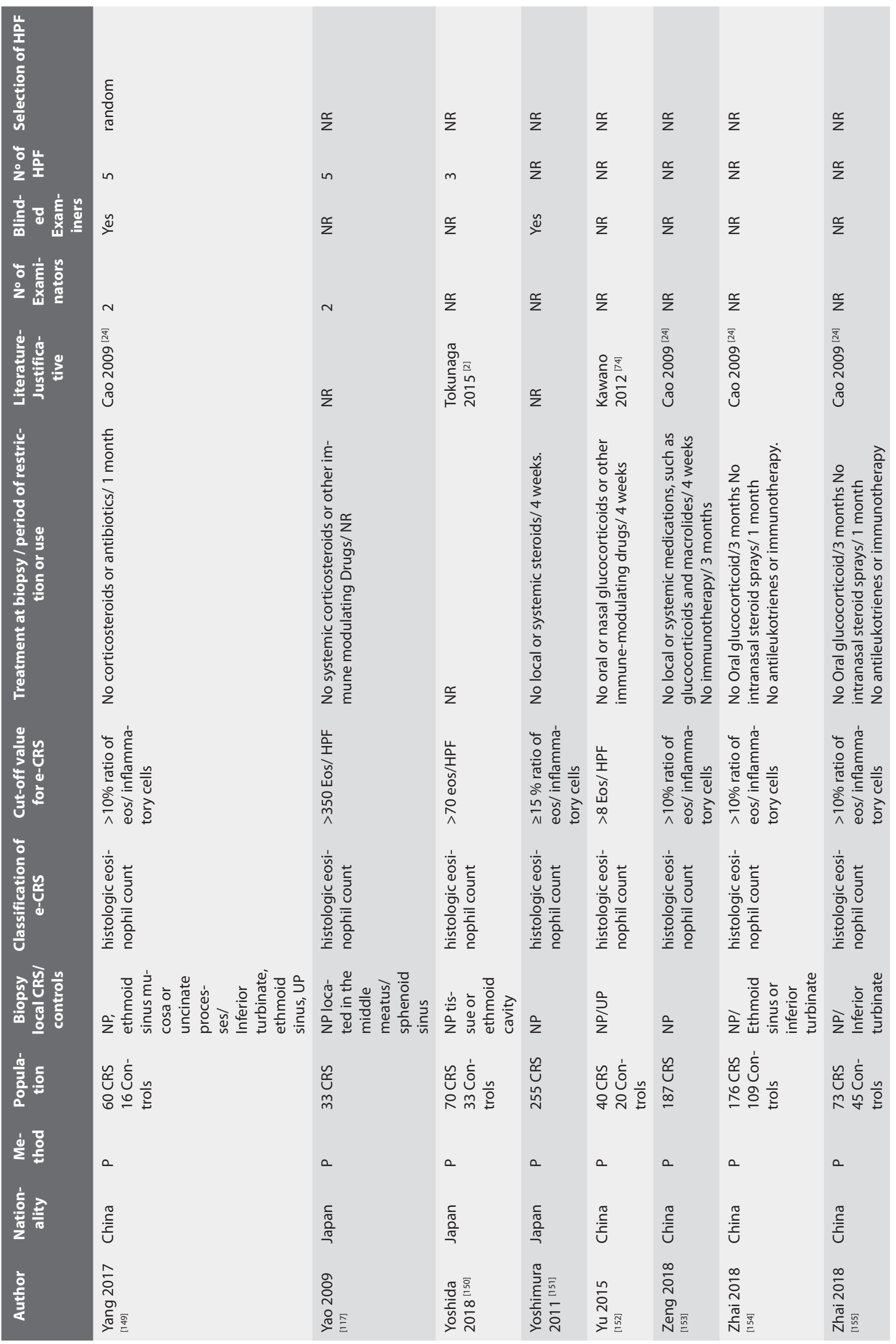




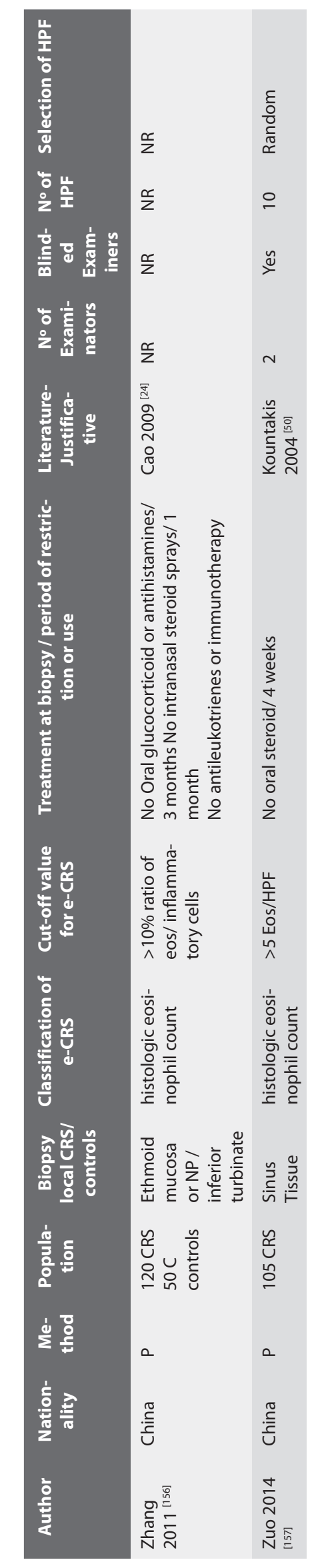

CRS: Chronic Rhinosinusitis, NP: Nasal Polyps, e-CRS: Eosinophilic Chronic rhinosinusitis, non-eCRS: Non Eosinophilic Chronic rhinosinusitis, CRSwNP: Chronic rhinosinusitis with nasal polyps, CRSsNP: Chronic rhinosinusitis without nasal polyps, Eos= eosinophils, HPF: High power field, SD: standard deviation, ROC : Receiver Operating Characteristic, QoL: quality of life, CT: computed tomography, P: prospective, R: retrospective, NR: not reported, JESREC: Japanese Epidemiological Survey of Refractory Eosinophilic Chronic Rhinosinusitis. 


\section{References}

1. Akiyama K, Makihara S, Uraguchi K, Samukawa Y, Oka A, Hoshikawa H. Impact of Preoperative Systemic Corticosteroids on the Histology and Diagnosis of Eosinophilic Chronic Rhinosinusitis. Int Arch Allergy Immunol 2019;179(2):81-8.

2. Tokunaga $T$, Sakashita M, Haruna $T$, et al. Novel scoring system and algorithm for classifying chronic rhinosinusitis: The JESREC Study. Allergy Eur J Allergy Clin Immunol 2015;70(8):995-1003.

3. Aslan F, Altun E, Paksoy S, Turan G. Could Eosinophilia predict clinical severity in nasal polyps? Multidiscip Respir Med 2017:12(1):1-5.

4. Soler ZM, Sauer D, Mace J, Smith TL. Impact of Mucosal Eosinophilia and Nasal Polyposis on Quality-of-Life Outcomes after Sinus Surgery. Otolaryngol Neck Surg 2010;142(1):64-71.

5. Snidvongs K, Lam M, Sacks R, et al. Structured histopathology profiling of chronic rhinosinusitis in routine practice. Int Forum Allergy Rhinol 2012;2(5):376-85.

6. Baba S, Kondo K, Toma-Hirano M, et al. Local increase in lgE and class switch recombination to IgE in nasal polyps in chronic rhinosinusitis. Clin Exp Allergy 2014;44(5):701-12.

7. Ishitoya J, Sakuma Y, Tsukuda M Eosinophilic chronic rhinosinusitis in Japan. Allergol Int 2010;59(3):239-45.

8. Baba S, Kondo K, Kanaya K, et al. Expression of IL-33 and its receptor ST2 in chronic rhinosinusitis with nasal polyps. Laryngoscope 2014;124(4):115-22.

9. Baba S, Kagoya R, Kondo K, Suzukawa M, Ohta K, Yamasoba T. T-cell phenotypes in chronic rhinosinusitis with nasal polyps in Japanese patients. Allergy, Asthma Clin Immunol 2015;11(1):1-11.

10. Baba S, Kondo K, Suzukawa M, Ohta K, Yamasoba T. Distribution, subtype population, and IgE positivity of mast cells in chronic rhinosinusitis with nasal polyps. Ann Allergy, Asthma Immunol 2017;119(2):120-8.

11. Barham HP, Osborn JL, Snidvongs K, Mrad N, Sacks R, Harvey RJ. Remodeling changes of the upper airway with chronic rhinosinusitis. Int Forum Allergy Rhinol 2015;5(7):56572.

12. Bellussi LM, Chen L, Chen D, Passali FM Passali D. The role of high mobility group box 1 chromosomal protein in the pathogenesis of chronic sinusitis and nasal polyposis. Acta Otorhinolaryngol Ital 2012;32(6):386-92.

13. Bonfils P, Badoual C, Bonfils NA, Gallas D, Malinvaud D. Eosinophil infiltration of nasal polyps in patients with nasal polyposis: Role in clinical evolution after medical and surgical treatment. J Laryngol Otol 2009;123(5):509-16.

14. Brescia G, Marioni G, Franchella S, et al. A prospective investigation of predictive parameters for post-surgical recurrences in sinonasal polyposis. Eur Arch Oto-RhinoLaryngology 2016;273(3):655-60.
15. Brescia G, Barion U, Pedruzzi B, et al. Sinonasal polyposis in the elderly. Am J Rhinol Allergy 2016;30(5):e153-6.

16. Brescia G, Barion U, Zanotti C, Parrino D, Marioni G. Pre-and postoperative blood neutrophil-to-lymphocyte and eosinophilto-lymphocyte ratios in patients with sinonasal polyps: A preliminary investigation. Allergy Asthma Proc 2017;38(5):e64-9.

17. Brescia G, Parrino D, Zanotti C, et al. Blood eosinophil and basophil values before and after surgery for eosinophilic-type sinonasal polyps. Am J Rhinol Allergy 2018;32(3):194201.

18. Brescia G, Schiavon F, Nicolè $L$, et al. No Differences in Nasal Tissue Inflammatory Cells and Adhesion Molecules (iCAM-1 and $v(A M-1)$ Based on the Comparison of EGPA With Eosinophilic Chronic Sinusitis With Polyposis. Am J Rhinol Allergy 2019;33(4):395-402.

19. Brescia G, Alessandrini L, Giacomelli L, et al. A classification of chronic rhinosinusitis with nasal polyps based on structured histopathology. Histopathology 2020;76(2):296-307.

20. De Borja Callejas F, Martínez-Antõn A Picado $C$, et al. Corticosteroid treatment regulates mucosal remodeling in chronic rhinosinusitis with nasal polyps. Laryngoscope 2015;125(5):E158-67.

21. Mastruzzo C, Greco LR, Nakano K, et al. Impact of intranasal budesonide on immune inflammatory responses and epithelial remodeling in chronic upper airway inflammation. J Allergy Clin Immunol 2003;112(1):37-44.

22. Garín L, Armengot M, Ramón Alba J, Carda C. Correlations Between Clinical and Histological Aspects in Nasal Polyposis. Acta Otorrinolaringol 2008;59(7):315-20.

23. Berger G, Kattan A, Bernheim J, Ophir D. Polypoid mucosa with eosinophilia and glandular hyperplasia in chronic sinusitis: A histopathological and immunohistochemical study. Laryngoscope 2002;112(4):73845.

24. Cao PP, Li H Bin, Wang BF, et al. Distinct immunopathologic characteristics of various types of chronic rhinosinusitis in adult Chinese. J Allergy Clin Immunol 2009;124(3):478-484.e2.

25. Wenzel SE, Schwartz LB, Langmack EL, et al. Evidence that severe asthma can be divided pathologically into two inflammatory subtypes with distinct physiologic and clinical characteristics. Am J Respir Crit Care Med 1999;160(3):1001-8.

26. Chen D, Mao M, Bellussi LM, Passali D, Chen L. Increase of high mobility group box chromosomal protein 1 in eosinophilic chronic rhinosinusitis with nasal polyps. Int Forum Allergy Rhinol 2014;4(6):453-62.

27. De Castro MCM, Rocha-Silva F, Gomes LI, et al. Impact of mitomycin $C$ on the mRNA expression signatures of immunological biomarkers in eosinophilic nasal polyposis. Am J Rhinol Allergy 2013;27(1):32-41.

28. Chen $F$, Hong $H$, Sun $Y$, et al. Nasal inter- leukin 25 as a novel biomarker for patients with chronic rhinosinusitis with nasal polyps and airway hypersensitiveness: A pilot study. Ann Allergy, Asthma Immunol 2017;119(4):310-316.e2.

29. Tao $X$, Chen $F$, Sun $Y$, et al. Prediction models for postoperative uncontrolled chronic rhinosinusitis in daily practice. Laryngoscope 2018;128(12):2673-80.

30. Chen $Z$, Peng $Y, N g C L$, et al. The clinical characteristics and histopathological features of chronic rhinosinusitis with unilateral nasal polyps in 136 patients in Southern China. Clin Otolaryngol 2018;43(5):1345-9.

31. Gao T, Ng CL, Li C, et al. Smoking is an independent association of squamous metaplasia in Chinese nasal polyps. Int Forum Allergy Rhinol 2016;6(1):66-74.

32. Cho KS, Kim YW, Kang MJ, Park HY, Hong $\mathrm{SL}$, Roh HJ. Immunomodulatory effect of mesenchymal stem cells on T lymphocyte and cytokine expression in nasal polyps. Otolaryngol - Head Neck Surg 2014;150(6):1062-70.

33. Cho SN, Song CH, Jin J, Kim SH, Rha KS, Kim YM. Role of staphylococcal enterotoxin $B$ on the differentiation of regulatory $T$ cells in nasal polyposis. Am J Rhinol Allergy 2014;28(1):17-24.

34. Czerny MS, Namin A, Gratton MA, Antisdel $J$. Histopathological and clinical analysis of chronic rhinosinusitis by subtype. Int Forum Allergy Rhinol 2014;4(6):463-9.

35. Ingels K, Durdurez JP, Cuvelier C, Van Cauwenberge P. Nasal biopsy is superior to nasal smear for finding eosinophils in nonallergic rhinitis. Allergy Eur J Allergy Clin Immunol 1997;52(3):338-41.

36. Do TQ, Barham HP, Earls $P$, et al. Clinical implications of mucosal remodeling from chronic rhinosinusitis. Int Forum Allergy Rhinol 2016;6(8):835-40.

37. Dutsch-Wicherek M, Tomaszewska R, Lazar A, et al. The evaluation of metallothionein expression in nasal polyps with respect to immune cell presence and activity. BMC Immunol 2010;11.

38. Feldman RE, Lam AC, Sadow PM, Bleier BS. P-glycoprotein is a marker of tissue eosinophilia and radiographic inflammation in chronic rhinosinusitis without nasal polyps. Int Forum Allergy Rhinol 2013;3(8):684-7.

39. Feng $X$, Ramsden MK, Negri J, et al. Eosinophil production of prostaglandin D2 in patients with aspirin-exacerbated respiratory disease. J Allergy Clin Immunol 2016;138(4):1089-1097.e3.

40. Mattos JL, Woodard CR, Payne SC. Trends in common rhinologic illnesses: Analysis of U.S. healthcare surveys 1995-2007. Int Forum Allergy Rhinol 2011;1(1):3-12.

41. Feng $X$, Payne SC, Borish L, Steinke JW Differential Expression of Extracellular Matrix Components in Nasal Polyp Endotypes. Am J Rhinol Allergy 2019;33(6):665-70.

42. Payne SC, Early SB, Huyett P, Han JK, Borish L, Steinke JW. Evidence for distinct histologic profile of nasal polyps with 
and without eosinophilia. Laryngoscope 2011;121(10):2262-7.

43. Furukawa M, Ogura M, Tsutsumi T, Tsuji H, Yamashita T. Presence of Platelet-activating Factor in Nasal Polyps and Eosinophils. Acta Otolaryngol 2002;122(8):872-6.

44. Jankowski R, F Bouchoua, L Coffinet JMV. Clinical Factors Influencing the Eosinophil Infiltration of Nasal Polyps. Rhinology 2002;40(4):173-8

45. Gitomer SA, Fountain CR, Kingdom TT, et al. Clinical Examination of Tissue Eosinophilia in Patients with Chronic Rhinosinusitis and Nasal Polyposis. Otolaryngol - Head Neck Surg 2016;155(1):173-8.

46. Grgić MV, Ćupić H, Kalogjera L, Baudoin T. Surgical treatment for nasal polyposis: predictors of outcome. Eur Arch Oto-Rhino-Lar yngology2015;272(12):3735-43.

47. Gu ZW, Jin MZ, Cao ZW. Role of eotaxin-3 in chronic rhinosinusitis with nasal polyps. Otolaryngol - Head Neck Surg 2011;145(2):324-6.

48. Günel C, Bleier BS, Meteoglu I. Antibiotics in eosinophilic chronic rhinosinusitis: Rethinking maximal antimicrobial medical therapy. Laryngoscope 2017;127(4):794-6.

49. Hamad WA, Khoueir N, Assily R, et al. Histopathological profile of nasal polyposis in Lebanon. Lebane Medical journal 2018;66(3):125-8

50. Kountakis SE, Arango P, Bradley D, Wade ZK, Borish L. Molecular and Cellular Staging for the Severity of Chronic Rhinosinusitis. Laryngoscope 2004;114(11):1895-905.

51. Hauser LJ, Chandra RK, Li P, Turner JH. Role of tissue eosinophils in chronic rhinosinusitis-associated olfactory loss. Int Forum Allergy Rhinol 2017;7(10):957-62.

52. Soy FK, Pinar E, Imre A, Calli C, Calli A, Oncel S. Histopathologic parameters in chronic rhinosinusitis with nasal polyposis: Impact on quality of life outcomes. Int Forum Allergy Rhinol 2013;3(10):828-33.

53. Hirotsu M, Kikuchi K, Kusunoki T, Kase K, Ono N, Ikeda K. Comparison of bacterial examinations between eosinophilic and neutrophilic chronic rhinosinusitis with nasal polyps. Acta Otolaryngol 2011;131(9):997-1001.

54. Hirotsu M, Shiozawa A, Ono N, Miwa M, Kikuchi K, Ikeda K. Fungal extracts detected in eosinophilic chronic rhinosinusitis induced cytokines from the nasal polyp cells. Laryngoscope 2014;124(9):347-53.

55. Ikeda K, Shiozawa A, Ono Net al. Subclassification of chronic rhinosinusitis with nasal polyp based on eosinophil and neutrophil. Laryngoscope 2013;123(11):1-9.

56. Saitoh $T$, Kusunoki $T$, Yao $T$, et al. Role of interleukin-17A in the eosinophil accumulation and mucosal remodeling in chronic rhinosinusitis with nasal polyps associated with asthma. Int Arch Allergy Immunol 2009;151(1):8-16

57. Ho J, Bailey M, Zaunders J, et al. Group 2 innate lymphoid cells (ILC2s) are increased in chronic rhinosinusitis with nasal polyps or eosinophilia. Clin Exp Allergy
2015;45(2):394-403

58. Ho J, Hamizan AW, Alvarado R, Rimmer J, Sewell WA, Harvey RJ. Systemic Predictors of Eosinophilic Chronic Rhinosinusitis. Am J Rhinol Allergy 2018;32(4):252-7.

59. Hu Y, Cao PP, Liang GT, Cui YH, Liu Z. Diagnostic significance of blood eosinophil count in eosinophilic chronic rhinosinusitis with nasal polyps in Chinese adults. Laryngoscope 2012;122(3):498-503.

60. Hupin C, Rombaux P, Bowen H, Gould H, Lecocq M, Pilette C. Downregulation of polymeric immunoglobulin receptor and secretory IgA antibodies in eosinophilic upper airway diseases. Allergy Eur J Allergy Clin Immunol 2013;68(12):1589-97.

61. Husain S, Pauzi SHM, Hamizan AKW, Gendeh BS, Lund VJ. Are all nasal polyps the same? Rawal Med J 2017;42(3):366-71.

62. Iinuma $T$, Okamoto $Y$, Yamamoto $H$, et al. Interleukin-25 and mucosal T cells in noneosinophilic and eosinophilic chronic rhinosinusitis. Ann Allergy, Asthma Immunol 2015;114(4):289-98.

63. Nakayama T, Yoshikawa M, Asaka D, et al, Mucosal eosinophilia and recurrence of nasal polyps - new classification of chronic rhinosinusitis. Rhinology 2011;49(4):3.

64. Ito T, Ikeda S, Asamori T, et al. Increased expression of pendrin in eosinophilic chronic rhinosinusitis with nasal polyps. Braz J Otorhinolaryngol 2019;85(6):760-5.

65. Jang YJ, Lim JY, Kim S, Lee Y La, Kweon MN Kim JH. Enhanced interferon- $\beta$ response contributes to eosinophilic chronic rhinosinusitis. Front Immunol 2018;9(OCT):1-11.

66. Lee M, Kim DW, Yoon $\mathrm{H}$, et al. Sirtuin 1 attenuates nasal polypogenesis by suppressing epithelial-to-mesenchymal transition. J Allergy Clin Immunol2016;137(1):87-98.e7

67. Jeong WJ, Lee $\mathrm{CH}$, Cho SH, Rhee CS. Eosinophilic allergic polyp: A clinically oriented concept of nasal polyp. Otolaryngol - Head Neck Surg 2011;144(2):241-6.

68. Jiang XD, Li GY, Li L, Dong Z, Zhu DD. The characterization of IL-17A expression in patients with chronic rhinosinusitis with nasal polyps. Am J Rhinol Allergy 2011;25(5):171-5

69. Jin J, Chang DY, Kim SH, et al. Role of hypoxia-inducible factor-1 a expression in regulatory $T$ cells on nasal polypogenesis. Laryngoscope 2014;124(5):151-9.

70. Jung HJ, Zhang YL, Kim DK, Rhee CS, Kim DY. The role of $\mathrm{nf}-\mathrm{kb}$ in chronic rhinosinusitis with nasal polyps. Allergy, Asthma Immunol Res 2019;11(6):806-17.

71. Kagoya R, Kondo K, Baba S, et al. Correlation of basophil infiltration in nasal polyps with the severity of chronic rhinosinusitis. Ann Allergy, Asthma Immunol 2015;114(1):30-5.

72. Kambara R, Minami T, Akazawa $\mathrm{H}$, et al. Lower Airway Inflammation in Eosinophilic Chronic Rhinosinusitis as Determined by Exhaled Nitric Oxide. Int Arch Allergy Immunol 2017:173(4):225-32.

73. Kato Y, Takabayashi T, Sakashita M, et al. Expression and functional analysis of CST1 in intractable nasal polyps. Am J Respir Cell Mol Biol 2018:59(4):448-57.

74. Kawano K, Kusunoki T, Ono N, et al. Heme oxygenase- 1 expression in chronic rhinosinusitis with eosinophilic infiltration. Auris Nasus Larynx 2012;39(4):387-92.

75. Kim DW, Kim DK, Eun KM, et al. Comparison between signature cytokines of nasal tissues in subtypes of chronic rhinosinusitis. Allergy, Asthma Immunol Res 2019;11(2):201-11.

76. Kim DW, Kim DK, Kim JY, et al. Elastasepositive neutrophils are associated with refractoriness of chronic rhinosinusitis with nasal polyps in an Asian population. Allergy, Asthma Immunol Res 2020;12(1):42-55.

77. Kim DW, Kim DK, Jo A, et al. Age-related decline of neutrophilic inflammation is associated with better postoperative prognosis in non-eosinophilic nasal polyps. PLoS One 2016;11(2):1-12.

78. Mahdavinia M, Suh LA, Carter RG, et al. Increased noneosinophilic nasal polyps in chronic rhinosinusitis in US second-generation Asians suggest genetic regulation of eosinophilia. J Allergy Clin Immunol2015;135(2):576-9.

79. Shin HW, Kim DK, Park MH, et al. IL-25 as a novel therapeutic target in nasal polyps of patients with chronic rhinosinusitis. J Allergy Clin Immunol 2015;135(6):14761485.e7.

80. Kim DW, Kulka M, Jo A, et al. Cross-talk between human mast cells and epithelial cells by IgE-mediated periostin production in eosinophilic nasal polyps. J Allergy Clin Immunol 2017;139(5):1692-1695.e6.

81. Kim JW, Hong SL, Kim YK, Lee CH, Min YG, Rhee CS. Histological and immunological features of non-eosinophilic nasal polyps. Otolaryngol - Head Neck Surg 2007;137(6):925-30.

82. Kim JW, Huh G, Rhee CS, et al. Unsupervised cluster analysis of chronic rhinosinusitis with nasal polyp using routinely available clinical markers and its implication in treatment outcomes. Int Forum Allergy Rhinol 2019;9(1):79-86.

83. Kim SY, Park JH, Rhee CS, Chung JH, Kim JW. Does eosinophilic inflammation affect the outcome of endoscopic sinus surgery in chronic rhinosinusitis in Koreans? Am J Rhinol Allergy 2013;27(6):166-9.

84. Kim JY, Cha MJ, Park YS, et al. Upregulation of FZD5 in Eosinophilic Chronic Rhinosinusitis with Nasal Polyps by Epigenetic Modification. Mol Cells 2019;42(4):345-55.

85. Kim SJ, Lee KH, Kim SW, Cho JS, Park YK, Shin SY. Changes in histological features of nasal polyps in a Korean population over a 17-year period. Otolaryngol - Head Neck Surg 2013;149(3):431-7.

86. Koyama T, Kariya S, Sato Y, et al. Significance of IgG4-positive cells in severe eosinophilic chronic rhinosinusitis. Allergol Int 2019:68(2):216-24.

87. Kuhar HN, Tajudeen BA, Heilingoetter A, et al. Distinct histopathologic features of radi- 
ation-induced chronic sinusitis. Int Forum Allergy Rhinol 2017;7(10):990-8.

88. Lee W, Chang L, Huang $Z$, et al. A Retrospective Analysis of $\gamma \delta \mathrm{T}$ Cel Expression in Chronic Rhinosinusitis and Its Association with Recurrence of Nasal Polyps. Orl 2017;79(5):251-63.

89. Liao B, Cao PP, Zeng M, et al. Interaction of thymic stromal lymphopoietin, IL-33, and their receptors in epithelial cells in eosinophilic chronic rhinosinusitis with nasa polyps. Allergy Eur J Allergy Clin Immunol 2015;70(9):1169-80

90. Liao B, Liu JX, Li ZY, et al. Multidimensional endotypes of chronic rhinosinusitis and their association with treatment outcomes. Allergy Eur J Allergy Clin Immunol 2018;73(7):1459-69

91. Lin $H$, Lin D, Xiong XS, Dai XX, Lin T. Role of platelet-derived growth factor-a in eosinophilic and non-eosinophilic chronic rhinosinusitis with nasal polyps. Int Forum Allergy Rhinol 2014;4(11):909-14.

92. Lin H, Li Z, Lin D, Zheng C, Zhang W. Role of NLRP3 Inflammasome in Eosinophilic and Non-eosinophilic Chronic Rhinosinusitis with Nasal Polyps. Inflammation 2016;39(6):2045-52.

93. Loesel LS. Immunopathologic study of chronic sinusitis: A proposal for atopic and non-atopic IgE-activated mast cell allergic inflammation. Ann Otol Rhinol Laryngol 2001;110(5 I):447-52

94. Lou H, Meng Y, Piao Y, Wang C, Zhang L, Bachert $C$. Predictive significance of tissue eosinophilia for nasal polyp recurrence in the Chinese population. Am J Rhinol Allergy 2015;29(5):350-6

95. Lou H, Meng Y, Piao Y, et al. Cellular phenotyping of chronic rhinosinusitis with nasal polyps. Rhinology 2016;54(2):150-9.

96. Ma J, Shi LL, Deng YK, et al. CD8+ T cells with distinct cytokine-producing features and low cytotoxic activity in eosinophilic and non-eosinophilic chronic rhinosinusitis with nasal polyps. Clin Exp Allergy 2016;46(9):1162-75.

97. Marino MJ, Garcia JO, Zarka M, Lal D. A structured histopathology-based analysis of surgical outcomes in chronic rhinosinusitis with and without nasal polyps. Laryngoscope Investig Otolaryngol 2019;4(5):497-503.

98. Matsuwaki Y, Ookushi T, Asaka D, et al. Chronic rhinosinusitis: risk factors for the recurrence of chronic rhinosinusitis based on 5-year follow-up after endoscopic sinus surgery. Int Arch Allergy Immunol 2008;146 (suppl 1):77-81.

99. Meng Y, Lou H, Wang C, Zhang L. Predictive significance of computed tomography in eosinophilic chronic rhinosinusitis with nasal polyps. Int Forum Allergy Rhinol 2016;6(8):812-9.

100. Mori E, Matsuwaki Y, Mitsuyama C, Okushi T, Nakajima T, Moriyama H. Risk factors for olfactory dysfunction in chronic rhinosinusitis. Auris Nasus Larynx 2013;40(5):465-9.

101. Meltzer EO, Hamilos DL, Hadley JA, et al.
Rhinosinusitis: Developing guidance for clinical trials. J Allergy Clin Immunol 2006;118(suppli 5):17-61.

102. Mortuaire G, Leroy X, Gengler I, Chevalier D, Prin L, Picry A. Histopathological classification of refractory chronic rhinosinusitis with nasal polips. Histol Histopathol 2015;30(12):1447-54.

103. Nakayama T, Asaka D, Yoshikawa M, et al. Identification of chronic rhinosinusitis phenotypes using cluster analysis. Am J Rhinol Allergy 2012;26(3):172-6.

104. Nakayama T, Asaka D, Kanaya H, Kuboki A, Haruna S ichi. Prognostic factors for recurrence after endoscopic sinus surgery for chronic rhinosinusitis with nasal polyps. Auris Nasus Larynx 2016:43(6):641-7.

105. Nakayama T, Sugimoto N, Okada N, et al. JESREC score and mucosal eosinophilia can predict endotypes of chronic rhinosinusitis with nasal polyps. Auris Nasus Larynx 2019:46(3):374-83.

106. Okada N, Nakayama T, Asaka D, et al. Distinct gene expression profiles and regulation networks of nasal polyps in eosinophilic and non-eosinophilic chronic rhinosinusitis. Int Forum Allergy Rhinol 2018;8(5):592-604.

107. Ono N, Kusunoki T, Miwa M, Hirotsu M, Shiozawa A, Ikeda K. Reduction in superoxide dismutase expression in the epithelial mucosa of eosinophilic chronic rhinosinusitis with nasal polyps. Int Arch Allergy Immunol 2013;162(2):173-80.

108. Papagiannopoulos P, Kuhar HN, Raman A, et al. Understanding the Propensity for Chronic Sinusitis in Patients on Immunosuppressive Therapy. Am J Rhinol Allergy 2018;32(6):478-84.

109. Papagiannopoulos P, Devins K, Tong CCL, et al. Chronic rhinosinusitis precipitated by tumor necrosis factor alpha inhibitors is the phenotype of chronic rhinosinusitis without nasal polyps. Int Forum Allergy Rhinol 2020;10(1):23-8.

110. Parrino D, Brescia G, Zanotti C, et al. NonEosinophilic Chronic Rhinosinusitis With Nasal Polyps: Eosinophil, Basophil, and Neutrophil Blood Counts Before and After Surgery. Ann Otol Rhinol Laryngol 2019;128(3):233-40.

111. Payne SC, Han JK, Huyett P, et al. Microarray analysis of distinct gene transcription profiles in non-eosinophilic chronic sinusitis with nasal polyps. Am J Rhinol 2008;22(6):568-81.

112. Plewka D, Grzanka A, Drzewiecka E, et al. Differential expression of tumor necrosis factor $a$, interleukin $1 \beta$, nuclear factor kb in nasal mucosa among chronic rhinosinusitis patients with and without polyps. Postep Dermatologii i Alergol 2017:34(3):199-206.

113. Fokkens WJ, Lund VJ, Mullol J, , et al. EPOS 2012: European position paper on rhinosinusitis and nasal polyps 2012. A summary for otorhinolaryngologists. Rhinol J 2012;50(1):1-12

114. Davide R, Chiara R, Giulio P, et al. Predictive markers of long-term recurrence in chronic rhinosinusitis with nasal polyps. Am J Otolaryngol - Head Neck Med Surg 2020;41(1):102286

115. Soler ZM, Sauer DA, Mace J, Smith TL. Relationship between clinical measures and histopathologic findings in chronic rhinosinusitis. Otolaryngol - Head Neck Surg 2009;141(4):454-61.

116. Wen W, Liu W, Zhang L, et al. Increased neutrophilia in nasal polyps reduces the response to oral corticosteroid therapy. J Allergy Clin Immunol 2012;129(6):15221528.e5.

117. Yao T, Kojima Y, Koyanagi A, et al. Eotaxin-1, -2 , and -3 immunoreactivity and protein concentration in the nasal polyps of eosinophilic chronic rhinosinusitis patients. Laryngoscope 2009;119(6):1053-9.

118. Tecimer SH, Kasapoglu F, Demir UL, Ozmen OA, Coskun H, Basut O. Correlation between clinical findings and eosinophil/neutrophil ratio in patients with nasal polyps. Eur Arch Oto-Rhino-Laryngology 2015;272(4):91521.

119. Tikaram A, Prepageran N. Asian nasal polyps: A separate entity? Med J Malaysia 2013;68(6):445-7.

120. Bhattacharyya N, Vyas DK, Fechner FP, Gliklich RE, Metson R. Tissue Eosinophilia in Chronic Sinusitis. Arch Otolaryngol Neck Surg 2001;127(9):1102.

121. Seif F, Ghalehbaghi B, Aazami $H$, et al. Frequency of CD4+ and CD8+ T cells in Iranian chronic rhinosinusitis patients. Allergy, Asthma Clin Immunol 2018;14(1):111.

122. Shen KH, Wang YH, Hsu TW, Hsieh LC, Sun FJ, Wang YP. Differential effects of postoperative oral corticosteroid on eosinophilic vs. non-eosinophilic CRSwNP subtypes. Am J Otolaryngol - Head Neck Med Surg 2019;40(1):22-9.

123.Snidvongs K, Chin D, Sacks R, Earls P, Harvey RJ. Eosinophilic rhinosinusitis is not a disease of ostiomeatal occlusion. Laryngoscope 2013;123(5):1070-4.

124. Shi LL, Xiong P, Zhang L, et al. Features of airway remodeling in different types of Chinese chronic rhinosinusitis are associated with inflammation patterns. Allergy Eur J Allergy Clin Immunol 2013;68(1):101-9.

125. Snidvongs K, Mclachlan R, Sacks R, Earls P, Harvey RJ. Correlation of the Kennedy Osteitis Score to clinico-histologic features of chronic rhinosinusitis. Int Forum Allergy Rhinol 2013;3(5):369-75.

126. Soler ZM, Sauer DA, Mace JC, Smith TL. Ethmoid histopathology does not predict olfactory outcomes after endoscopic sinus surgery. Am J Rhinol Allergy 2010;24(4):281-5.

127. Szucs E, Ravandi S, Goossens A, Beel M, Clement PAR. Eosinophilia in the ethmoid mucosa and its relationship to the severity of inflammation in chronic rhinosinusitis. Am J Rhinol 2002;16(3):131-4.

128. Rothenberg ME. Eosinophilia. N Engl J Med1998:338(22):1592-600.

129. Tajudeen BA, Ganti A, Kuhar HN, et al. The 
presence of eosinophil aggregates correlates with increased postoperative prednisone requirement. Laryngoscope 2019;129(4):794-9.

130. Tang R, Li ZP, Li MX, et al. Pro-inflammatory role of transient receptor potential canonical channel 6 in the pathogenesis of chronic rhinosinusitis with nasal polyps. Int Forum Allergy Rhinol 2018;8(11):1334-41.

131. Teranishi Y, Jin D, Takano S, Sunami K, Taka $S$. Decrease in number of mast cells in resected nasal polyps as an indicator for postoperative recurrence of chronic rhinosinusitis. Immun Inflamm Dis2019;7(3):191200.

132. Terna E, Luukkainen A, Seppälä M,et al. The expression of cancerous inhibitor protein phosphatase 2A in chronic rhinosinusitis with nasal polyps. Acta Otolaryngol 2016;136(11):1173-9.

133. Thaitrakool W, Sukswai N, Keelawat S, et al. Histopathology of ethmoid mucosa versus polyp tissue in diagnosing eosinophilic mucin rhinosinusitis. Rhinology 2019;57(1):67-72.

134. Tojima I, Kouzaki H, Shimizu S, et al. Group 2 innate lymphoid cells are increased in nasal polyps in patients with eosinophilic chronic rhinosinusitis. Clin Immunol 2016;170:1-8.

135. Tsutsumiuchi T, Hoshino H, Fujieda S, Kobayashi M. Induction of peripheral lymph node addressin in human nasal mucosa with eosinophilic chronic rhinosinusitis. Pathology 2019;51(3):268-73

136. Uraguchi K, Kariya S, Makihara S, et al. Pulmonary function in patients with eosinophilic chronic rhinosinusitis. Auris Nasus Larynx 2018;45(3):476-81.

137. Vento SI, Ertama LO, Hytönen ML, Wolff CHJ, Malmberg $\mathrm{CHO}$. Nasal polyposis: Clinical course during 20 years. Ann Allergy, Asthma Immunol 2000;85(3):209-14.

138. Holopainen E, Mäkinen J, Paavolainen M, Palva T, Salo OP. Nasal polyposis relationships to allergy and acetylsalicylic acid intolerance. Acta Otolaryngol 1979;87(36):330-4
139. Vlaminck S, Vauterin T, Hellings PW, et al The importance of local eosinophilia in the surgical outcome of chronic rhinosinusitis: A 3-year prospective observational study. Am J Rhinol Allergy 2014;28(3):260-4.

140. Wang C, Lou H, Wang X, et al. Effect of budesonide transnasal nebulization in patients with eosinophilic chronic rhinosinusitis with nasal polyps. J Allergy Clin Immunol 2015;135(4):922-929.e6.

141. Wang K, Deng J, Yang M, et al. Concordant systemic and local eosinophilia relates to poorer disease control in patients with nasal polyps. World Allergy Organ J 2019;12(8):100052.

142. Wei Y, Ma R, Zhang J, et al. Excessive periostin expression and Th2 response in patients with nasal polyps: Association with asthma. J Thorac Dis 2018;10(12):6585-97.

143.Wu D, Mueller SK, Nocera AL, Finn K, Libermann TA, Bleier BS. TREM-1 Neutrophi Activation Pathway Is Suppressed in Eosinophilic Nasal Polyps. Am J Rhinol Allergy 2018;32(5):359-68.

144. Wu X, Hong H, Zuo K, et al. Expression of leukotriene and its receptors in eosinophilic chronic rhinosinusitis with nasal polyps. Int Forum Allergy Rhinol 2016;6(1):75-81.

145. Xie L, Liu AG, Cui YH, et al. Expression profiles of prostaglandin E2 receptor subtypes in aspirin tolerant adult Chinese with chronic rhinosinusitis. Am J Rhinol Allergy 2015;29(5):322-8

146.Xu M, Ye X, Zhao F, He Y, Chen L. Allergogenic profile in patients with different subtypes of chronic rhinosinusitis with nasal polyps. Orl 2015;77(1):10-6.

147. Yamada T, Miyabe Y, Ueki S, et al. Eotaxin-3 as a plasma biomarker for mucosal eosinophil infiltration in chronic rhinosinusitis. Front Immunol 2019;10:1-9.

148. Yan B, Lou H, Wang $Y$, et al. Epitheliumderived cystatin SN enhances eosinophil activation and infiltration through IL-5 in patients with chronic rhinosinusitis with nasal polyps. J Allergy Clin Immunol 2019;144(2):455-69.
149. Yang $L$, Li X, Li W, et al. $V_{\gamma} 1+\gamma \delta T$ cells are correlated with increasing expression of eosinophil cationic protein and metalloproteinase-7 in chronic rhinosinusitis with nasal polyps inducing the formation of edema. Allergy, Asthma Immunol Res 2017;9(2):142-51.

150. Yoshida K, Takabayashi T, Imoto Y, Sakashita M, Narita N, Fujieda S. Reduced nasal nitric oxide levels in patients with eosinophilic chronic rhinosinusitis. Allergol Int 2019;68(2):225-32.

151. Yoshimura K, Kawata R, Haruna S, et al. Clinical epidemiological study of 553 patients with chronic rhinosinusitis in Japan. Allergol Int 2011;60(4):491-6.

152. Yu Z, Wang Y, Zhang J, et al. Expression of heme oxygenase-1 in eosinophilic and non-eosinophilic chronic rhinosinusitis with nasal polyps: Modulation by cytokines. Int Forum Allergy Rhinol 2015;5(8):734-40.

153.Zeng $M$, Wang $H$, Long XB, et al. Comparison of efficacy of fluticasone propionate versus clarithromycin for postoperative treatment of different phenotypic chronic rhinosinusitis: a randomized controlled trial. Rhinol J 2018;1-11.

154.Zhai GT, Wang H, Li JX, et al. IgD-activated mast cells induce IgE synthesis in B cells in nasal polyps. J Allergy Clin Immunol 2018;142(5):1489-1499.e23.

155.Zhai GT, Li JX, Zhang XH, Liao B, Lu X, Liu Z. Increased accumulation of CD30 ligand-positive mast cells associates with eosinophilic inflammation in nasal polyps. Laryngoscope 2019;129(3):E110-7.

156.Zhang $X H$, Zhang $Y N$, Li HB, et al. Overexpression of miR-125b, a novel regulator of innate immunity, in eosinophilic chronic rhinosinusitis with nasal polyps. Am J Respir Crit Care Med 2012;185(2):140-51.

157. Zuo K, Guo J, Chen F, et al. Clinical characteristics and surrogate markers of eosinophilic chronic rhinosinusitis in Southern China. Eur Arch Oto-Rhino-Laryngology 2014;271(9):2461-8. 